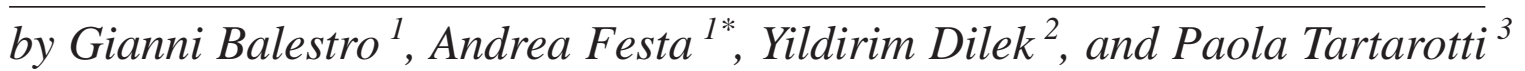

\title{
Pre-Alpine extensional tectonics of a peridotite- localized oceanic core complex in the Late Jurassic, high-pressure Monviso ophiolite (Western Alps)
}

1 Dipartimento di Scienze della Terra, Università di Torino, Via Valperga Caluso, 35, 10125 - Torino, Italy 2 Department of Geology and Environmental Earth Science, Miami University, Oxford, OH 45056, USA 3 Dipartimento di Scienze della Terra, Università di Milano, Via Mangiagalli, 34, 20133 - Milano, Italy

*Corresponding author: Andrea Festa. E-mail: andrea.festa@unito.it

DOI: 10.18814/epiiugs/2015/v38i4/82421

The Late Jurassic Monviso ophiolite in the Western Alps is a multiply deformed, eclogite-facies metaophiolite that represents a remnant of the Alpine Tethyan oceanic lithosphere. The recent recognition of a preAlpine detachment fault in the Lower Tectonic Unit of this ophiolite has led to the discovery of an oceanic core complex, which developed during the initial stages of the tectonic evolution of the Alpine Tethys. The NNWstriking, 20-25-km-long shear zone (Baracun Shear Zone) contains ductilely to cataclastically deformed blocks and clasts of Fe-Ti and Mg-Al metagabbros in a matrix made of mylonitic serpentinite and talc-chlorite schist with high $\mathrm{Ni}-\mathrm{Cr}$ concentrations and high $\mathrm{Cl}$ contents. Intensely sheared ophicarbonate rocks and brecciated serpentinite within this shear zone are deformed by the Alpine-phase S1 foliation and D2 folds, providing a critical age constraint for the timing of its formation. Metabasaltic-metasedimentary rocks in the hanging wall increase in thickness away from the shear zone, characteristic of syn-extensional rock sequences in supradetachment basins. A Lower Cretaceous post-extensional sedimentary sequence unconformably cover the syn-extensional strata, the detachment shear zone, and the ophiolitic footwall, establishing a strong structural evidence for the intraoceanic, seafloor spreading origin of the tectonic fabric of the Monviso ophiolite, prior to the onset of subduction zone tectonics in the Alpine Tethys. The Monviso ophiolite and the Baracun Shear Zone represent a peridotite-localized oceanic core complex, which survived both the subduction and continental collision tectonic stages of the Alpine orogeny. Intraoceanic detachment faults and oceanic core complexes may play a significant role in subduction initiation, and hence their recognition in orogenic belts is an important step in reconstructing the record of ocean basin collapse and closure.

\section{Introduction}

Discontinuous exposures of the Late Jurassic, eclogitic ophiolite massifs in the Western Alps (Fig. 1) have been widely used in various studies to constrain the paleogeography of the Alpine Tethys, evolved between Europe and Adria during the Mesozoic (Dilek and Robinson, 2003, and the papers therein). They, in particular, have been well utilized to determine the P-T-t trajectories of the Jurassic oceanic crust in a subduction-accretion system during the convergent-collision tectonic evolution of this orogenic belt (e.g., Frey et al., 1999). However, detailed, field-based structural, petrological and geochemical studies of the seafloor spreading and extensional tectonic history of these ophiolites have been scarce. This has been in part due to the strong overprint of the Alpine-stage subduction-collision related deformation-metamorphic events that obscures the previously developed rift-drift and seafloor spreading generated structures and mineral assemblages in these units.

In this paper, we document through detailed geological mapping, systematic structural and stratigraphic observations, petrographic and geochemical analyses the internal structure, tectonic fabric and evolution history of the Monviso ophiolite, one of the best preserved ophiolites in the Western Alps. We show that this ophiolite is an onland exposure of an oceanic core complex, which formed through simple-shear seafloor spreading kinematics during the opening of the Ligurian-Piedmont ocean basin within the Alpine Tethys. This inferred 
oceanic core complex origin of the Monviso ophiolite is significant in that: (1) it better explains the dismembered and highly attenuated crustal architecture of the ophiolites in the Western Alps; (2) it presents a first coherent documentation of the intraoceanic extensional tectonic history of the Jurassic oceanic lithosphere preserved in the Western Alps, demonstrating that it is possible "to see through" the subductioncollision induced metamorphic overprint in multiply deformed orogenic belts; and (3) it provides a regionally consistent tectonic framework for the rift-drift, seafloor spreading, and contractional episodes of the Ligurian - Piedmont ocean basin evolution. Our data and observations from the Monviso ophiolite complement the diverse datasets available from the modern oceanic core complexes, and provide further insights into the geometry, internal structure, and stratigraphy of supradetachment basin sequences, which are missing from in-situ oceanic core complexes.

\section{Regional geology of the Western Alps and its Tethyan connection}

The Western Alps (Fig. 1) developed due to the collision between Adria (upper plate) and Europe (lower plate) as the intervening oceanic lithosphere of the Jurassic Alpine Tethys Ocean was consumed (see e.g. Coward and Dietrich 1989; Laubscher 1991; Dilek, 2006). The collision zone (i.e. the axial section of the Alpine belt) involves an exhumed fossil subduction complex bounded by the Penninic front and the Insubric and Canavese lines (Fig. 1A). Tectonic units of this subduction complex are overthrust WNW onto the European foreland (Ricou and Siddans, 1986; Platt et al. 1989; Schmid and Kissling 2000; Butler et al. 2013). Different meta-ophiolite units (i.e. the Piedmont Zone; see e.g. Dal Piaz et al., 2003) are tectonically sandwiched between the European and Adriatic continental margin units (see Bigi et al., 1990), and display varying metamorphic facies conditions ranging from high-pressure (HP) to ultra high-pressure (UHP) (Frey et al., 1999 and reference therein). The Piedmont Zone is distinguished by eclogite-facies units (i.e. the Zermatt-Saas Zone auct.;Bearth, 1967) and blueschist-facies ones (i.e. the Combin Zone auct., Fig. 1A).

The orogenic structural architecture of the Western Alps as seen in the field today (Fig. 1) was built up during three main phases of deformation-metamorphism events: (1) E-dipping subduction zone tectonics and eclogite-facies metamorphism in the Paleocene to middle Eocene, during which contractional deformation (D1) structures, mainly S1 foliation, were developed; (2) Continental collision tectonics in the late Eocene-early Oligocene that caused W-vergent folding and thrusting (D2). Blueschist- to greenschist-facies metamorphic re-equilibration took place during this event, producing S2 foliation; (3) Crustal exhumation (D3) and deep crust/mantle indentation in the middle Oligocene to Neogene. Updoming of the partially subducted European continental margin, the UHP Dora Maira, and the tilting of the Monviso ophiolite to the west (Fig. 1B) occurred during this late Alpine stage evolution of the Western Alps (see e.g. Lardeaux et al., 2006).

The meta-ophiolites in the Western Alps are the remnants of the Alpine Tethyan oceanic lithosphere, which developed as a result of its rift-drift and seafloor spreading evolution (Elter, 1971; Dal Piaz et al., 1972; Lemoine and Tricart., 1986; Stampfli and Marthaler, 1990; Michard et al., 1996; Dilek, 2003; Dilek and Furnes, 2011, 2014; Saccani et al., 2015). The timing of drifting and spreading has been constrained by $\mathrm{U} / \mathrm{Pb}$ dating of ophiolitic gabbros between 165 and $150 \mathrm{Ma}$ (Manatschal and Müntener, 2009 for a review), and by the ages of the initial post-rift sedimentary sequences (i.e. radiolarian chert) that overlap with the igneous ages of gabbros (see Bill et al, 2001, for a review). Paleo-spreading rates in the Alpine Tethys are inferred to have been slow- to ultraslow ( $2 \mathrm{~mm} / \mathrm{yr}$ ) (see Lagabrielle, 2009 , for a review), forming a Red Sea-type, embryonic ocean (Lombardo et al., 2002). This ultraslow-spreading origin interpretation is based, in part, on the occurrence of basaltic lava units directly resting on serpentinized peridotites. These spatial relationships between upper mantle peridotites and lavas with sedimentary intercalations and cover are well documented from modern oceanic core complexes, rifted continental margins, and some other Tethyan ophiolites (Dilek and Delaloye, 1992; Dilek and Eddy, 1992; Dilek et al., 1998; Miranda and Dilek, 2010; Manatschal et al., 2011; Festa et al., 2015a). Simple-shear extensional deformation in these tectonic settings is shown to have exhumed the lithospheric mantle rocks on the seafloor during the rift-drift and seafloor spreading stages of ocean basin evolution (Dilek and Thy, 1998; Dilek and Newcomb, 2003, and the papers therein).

\section{Monviso ophiolite}

The Monviso ophiolite occurs in the southern part of the Western Alps (Fig. 1), and is tectonically sandwiched between the Dora Maira Unit (Internal Cristalline Massif Auct.), which represents part of the subducted-exhumed European continental margin (e.g., Dal Piaz et al., 2003) and the Queyras Schistes Lustrés Complex (Lemoine, 1971; Lombardo et al., 1978; Lemoine and Tricart, 1986). The carbonaterich metasedimentary sequence of schistes lustrés hosts large bodies of ophiolites, which comprise ophicarbonates and metaperidotites with gabbroic intrusions. This metasedimentary sequence includes discontinuous exposures of Middle-Late-Jurassic metachert horizons and laterally continuous Upper Jurassic marble layers covering the entire igneous basement (e.g., Tricart and Lemoine, 1991; Tricart and Schwartz, 2006).

The Monviso ophiolite consists mainly of serpentinized metaperidotites hosting large bodies of both $\mathrm{Mg}$-Al and $\mathrm{Fe}-\mathrm{Ti}$ metagabbros. These metagabbros have Middle-Late Jurassic crystallization ages (163 2 Ma; Rubatto and Hermann, 2003). The upper mantle rocks are composed of lherzolite and minor harzburgite, and are overlain along tectonic contacts by tholeiitic pillow metalavas, and an Upper Jurassic - Lower Cretaceous meta-sedimentary sequence (Balestro et al., 2013). The Monviso ophiolite has been divided into two major tectonic units on the basis of their different Alpine-stage P-T metamorphic peaks (Fig. 1C). The Lower Tectonic Unit (LTU) includes the metaperidotites, metagabbros, metabasalts, and a shear zone made of mylonitic serpentinite and talc-chlorite schist. Overlying this unit along a WSW-dipping tectonic contact is the Upper Tectonic Unit (UTU), which is composed mainly of metabasaltic lavas and metagabbro intrusions. The LTU lithologies display peak metamorphic P-T conditions of $2.5 \mathrm{GPa}-550^{\circ} \mathrm{C}$ (Groppo and Castelli, 2010; Angiboust et al., 2012; Balestro et al., 2014). The UTU lithologies show, on the other hand, peak metamorphic P-T conditions of $2.2 \mathrm{GPa}-480^{\circ} \mathrm{C}$ (Angiboust et al., 2012). Thus, the ophiolite exhibits a major tectonic discontinuity separating two different metamorphic domains in it. Another major tectonic discontinuity occurs within the Lower Tectonic Unit (LTU), in which a NNW-striking, >20-km-long shear zone (Baracun Shear Zone, BSZ) separates the serpentinized 

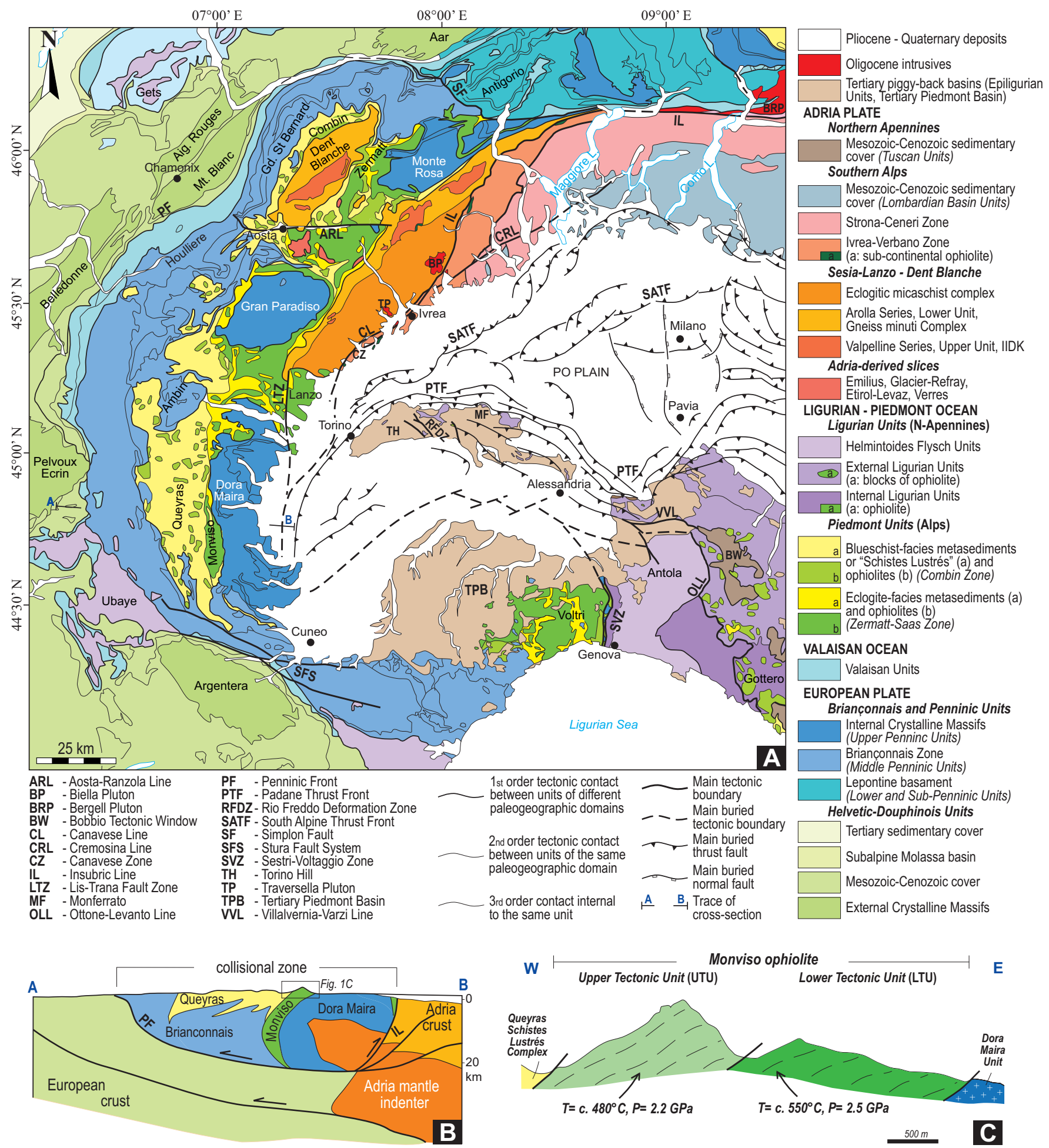

Figure 1 - (A) Tectonic map of the Western Alps and the Northern Apennines (modified from Bigi et al., 1990; Bousquet et al., 2012; Fantoni et al., 2003, 2004; Funicello et al., 1981; Ghibaudo et al., 2014; Ghielmi et al., 2013; Manzotti et al., 2014; Festa et al., 2015b, 2015c; Perrone et al., 2015). (B) Tectonic cross-section across the Western Alps (modified from Lardeaux et al., 2006). The box shows the westward titled Monviso ophiolite, enlarged in Figure 1C. (C) Simple structural cross section of the Monviso ophiolite, sandwiched between the UHP Dora Maira Unit and the Queyras Schistes Lustrés, and showing two different metamorphic domains (modified from Angiboust et al., 2012). 

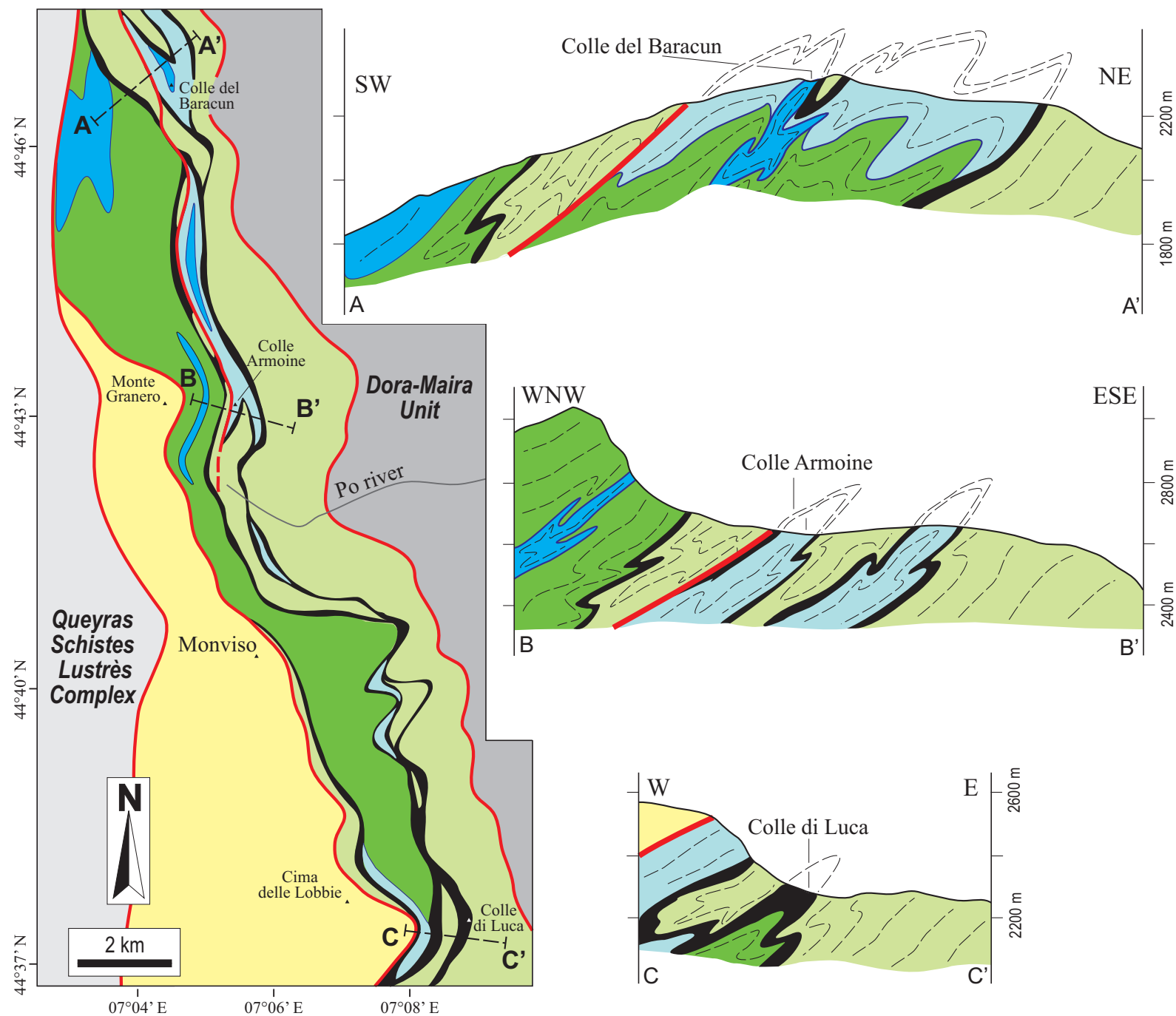

ESE

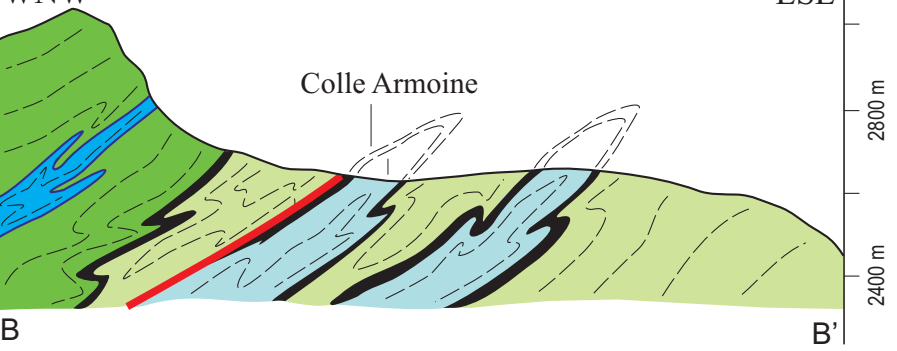

Monviso ophiolite (MO)
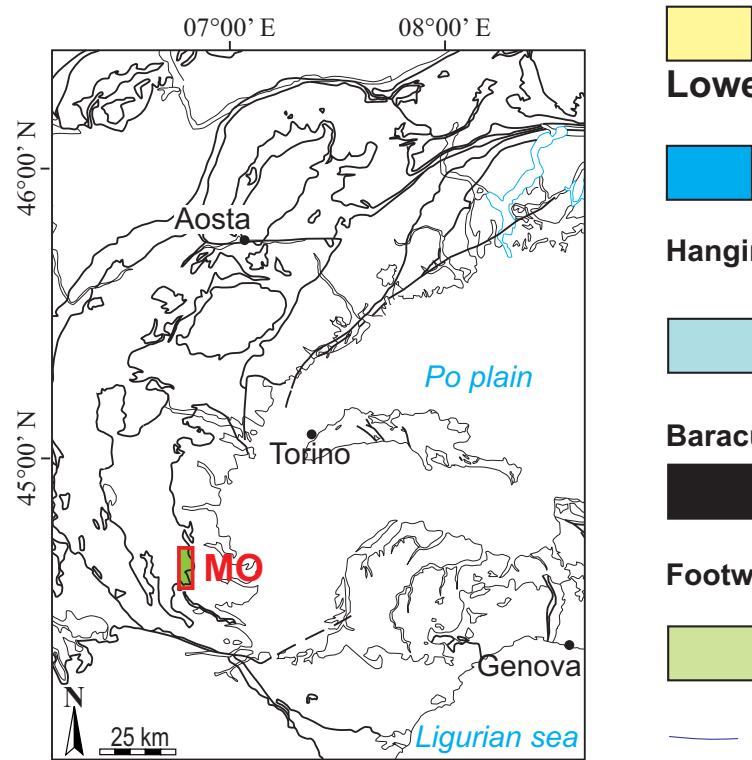

Undifferentiated Upper Tectonic Unit (UTU).

\section{Lower Tectonic Unit (LTU)}

Post-extensional succession (Early Cretaceous)

Calcschist alternating with marble and quartz-rich schist.

\section{Hanging-wall Unit}

\section{Unconformity}

Syn-extensional succession (Late Jurassic)

Calcschist and horizons of mafic metabreccia and Metabasalt with minor metasandstone.

\section{Baracun Shear Zone}

Talc-and-chlorite schist and mylonitic serpentinite with blocks of Mg-Al and Fe-Ti metagabbro.

\section{Footwall Unit}

Serpentinized metaperidotite with bodies of Mg-Al and Fe-Ti metagabbro, and horizons of sheared meta-ophicalcite (Middle-Late Jurassic?)

Lithological contact Alpine-related

$\stackrel{x}{\mapsto}-x^{\prime}$ Cross-section

Figure 2. Geological map and structural cross-sections (A-A'through C-C') of the Lower Tectonic Unit (LTU) of the Monviso ophiolite (MO) (modified from Balestro et al., 2011, 2013, 2014, 2015), depicting the geometry of the Baracun Shear Zone (BSZ), its hanging wall and footwall units and the post-extensional metasedimentary sequence. The index map shows the location of the Monviso geological map and the geography of the Western Alps. 
metaperidotites and metagabbros in its footwall from metabasalt and syn-extensional metasedimentary rocks in the hanging wall (Fig. 2). Both the footwall and hanging wall units are unconformably overlain by the Lower Cretaceous, post-extensional metasedimentary rocks (Festa et al., 2015a).

\section{Structural architecture and stratigraphy of the LTU}

Different lithologies and the BSZ in the LTU are pervasively folded during D2 deformation (see Balestro et al., 2014, 2015; Festa et al., 2015a for major details; Fig. 2), forming tight to isoclinal folds accompanied by a SW- to W-dipping axial planar foliation (i.e. the $\mathrm{S} 2$ foliation). These D2 folds deform the earlier formed S1 foliation and the primary surfaces (i.e. the S0 sedimentary bedding and magmatic foliation). Extensional normal faults, representing the D3 stage of deformation, are commonly localized along lithological contacts and the attenuated limbs of the D2 folds.

We describe below the structural architecture of the BSZ and the stratigraphy and structure of various tectonostratigraphic units in its footwall and hanging wall blocks. We also define and describe the post-extensional metasedimentary sequence that onlap all these tectonic entities in the LTU. These descriptions are based largely on our detailed structural work and observations in the Colle del Baracun, Colle Armoine, and Colle di Luca (Fig. 2) sections of the Monviso ophiolite.

\section{Baracun Shear Zone (BSZ)}

The BSZ is tens of meters thick and includes talc-chlorite schist and mylonitic serpentinite, containing blocks of metagabbro displaying a scale-independent block-in-matrix fabric (Figs. 3A-L; sensu Festa, 2011; Festa et al., 2012). Due to the macroscopic-scale folding (D2), the BSZ occurs at different structural levels within the ophiolite (Fig. 2). It does not contain any material derived from the lithological units in its hanging wall. It corresponds to the Lower Shear Zone of Angiboust et al. (2011) and to the Lago Superiore Shear Zone of Balestro et al. (2013).

In its type locality at Colle del Baracun, the BSZ includes a talcchlorite schist matrix with distinct chlorite-, talc-, and amphibolerich domains (Fig. 3C). The chlorite-rich domains consist of chlorite, magnetite, pistacite, and accessory apatite, magnetite, allanite and zircon, and mainly occur in rootless hinges of D2 folds, which folded the $\mathrm{S} 1$ foliation (Fig. 3M). Pre-D1 talc and chlorite lamellae are also included in apatite grains. Talc-rich domains in the talc-chlorite schist matrix are composed of talc and fine-grained magnetite, and occur in two different modes. In the first one, fine-grained aggregates of talc and magnetite appear within the D2 fold hinges. In the second mode, coarse-grained talc lamellae are oriented in the S2 foliation plane. Talc-rich domains are commonly folded together with chlorite-rich domains or form anastomosing crenulation cleavages with microlithons of the rock that contain S1 and S2 foliations (Fig. 3M; see also Fig. 3N). Amphibole-rich domains include fine-grained, lightgreen amphibole and minor chlorite. Calcite locally occurs between these different mineral domains in the matrix. In the Colle Armoine and Colle di Luca sections, the matrix consists of $\mathrm{dm}$ - to m-thick layers of talc-chlorite schist, which is interbedded within mylonitic serpentinite (Figs. 3D and 3E). The serpentinite consists mainly of antigorite and magnetite, with minor brucite, talc and carbonate.

Blocks of Fe-Ti metagabbro and $\mathrm{Mg}$-Al metagabbro, ranging in size from few $\mathrm{dm}$ to several meters, widely occur within the talcchlorite schist and in the mylonitic serpentinite matrix throughout the shear zone (Figs. 3A and 3D). These gabbro blocks are also folded by D2 folds, and locally occur as rootless fold hinges of D2 folds (Fig. 3B). Fe-Ti metagabbro blocks display a fine-grained, banded texture defining the $\mathrm{S} 1$ foliation and consisting of a mineral assemblage of garnet-omphacite-rutile eclogite with minor chlorite, Na-amphibole, albite, talc and quartz. Omphacite porphyroblasts locally preserve relics of the magmatic pyroxene and retain finegrained intergrowths of quartz and amphibole. The amphibole is represented by $\mathrm{Mg}$-hastingsitic hornblende replacing primary igneous

Figure 3. Images of the Baracun Shear Zone (BSZ) and structures at different scales: (A) Panoramic view of the BSZ at the Colle del Baracun, showing its block-in-matrix fabric. White arrows point tothe blocks of Fe-Ti and Mg-Al metagabbros, and to some rare blocks of metarenite embedded in a matrix of talc-chlorite schist. Yellow arrows indicate the younging direction of the primary sedimentary sequence, now folded by Alpine deformation. Post-extensional sedimentary rocks rest unconformably (dotted blue line) on both the syn-extensional sequence and the talc-chlorite schist of the BSZ; (B) Close-up photo of one of the larger metagabbro blocks embedded within the BSZ matrix (location in Fig. 3A).The shape of the block corresponds to the fold hinge of a D2 fold, which deformed the previously formed foliation S1. Note the mafic metabreccia enveloping the block (see also Figs. 3F, 3G, 3I, 3L). Hammer for scale; (C) Close-up of the structural fabric of the talc-chlorite schist matrix at Colle del Baracun (hammer as scale); (D) Close-up of of the block-in-matrix fabric of the BSZ at Colle di Luca. Rounded to elongated blocks of gabbro (black arrows) are embedded within a mylonitic serpentinite matrix affected by D2 foliation (dashed white lines); (E)Talc-chlorite schist matrix of the BSZ at Colle di Luca; (F) Close-up of a Fe-Ti metagabbro block within the BSZ, enveloped by a dm-thick horizon of a clast-supported mafic metabreccia outcrop (black arrows), with clasts of the same composition as in the main block (Colle del Baracun); $(G)$ Close-up of the contact between the clast-supported mafic metabreccia enveloping the metagabbro blocks and the talc-chlorite schist matrix, embedding rounded blocks of metagabbro, centimeters to decimeters in size (Colle di Luca). Hammer as scale; (H and I) Close-up of the mafic metabreccia enveloping blocks of gabbro. Note that irregularly shaped clasts, centimeters to decimeters in size, preserve an earlier formed foliation, S1, folded by D2 deformation (Colle di Luca and Colle del Baracun, respectively); (L) Photomicrograph showing the clast/matrix relationship within the mafic metabreccia of Figure $3 I$ (modified after Balestro et al., 2015). The matrix and the irregularly shaped clast (dashed blue line) are affected by S1 foliation (dashed red line), which is defined by an eclogite-facies mineral assemblage (i.e. garnet, omphacite, and rutile); (M) Photomicrograph of talc-chlorite schist in the BSZ at Colle del Baracun, showing amphibole- (Amp), chlorite- (Chl) and talc-rich (Tlc) domains folded by tight to isoclinal D2 folds. Note the folded S1 foliation (dashed white lines); (N) Close-up of a polished hand sample of the talc-chlorite schist matrix (Colle del Baracun), showing rootless $D 2$ fold hinges in chlorite-rich (Chl) domains, overprinting the early S1 foliation (dashed white lines). S2 axial planar foliation (dashed black lines) occurs in talc-rich (Tlc) domains. 

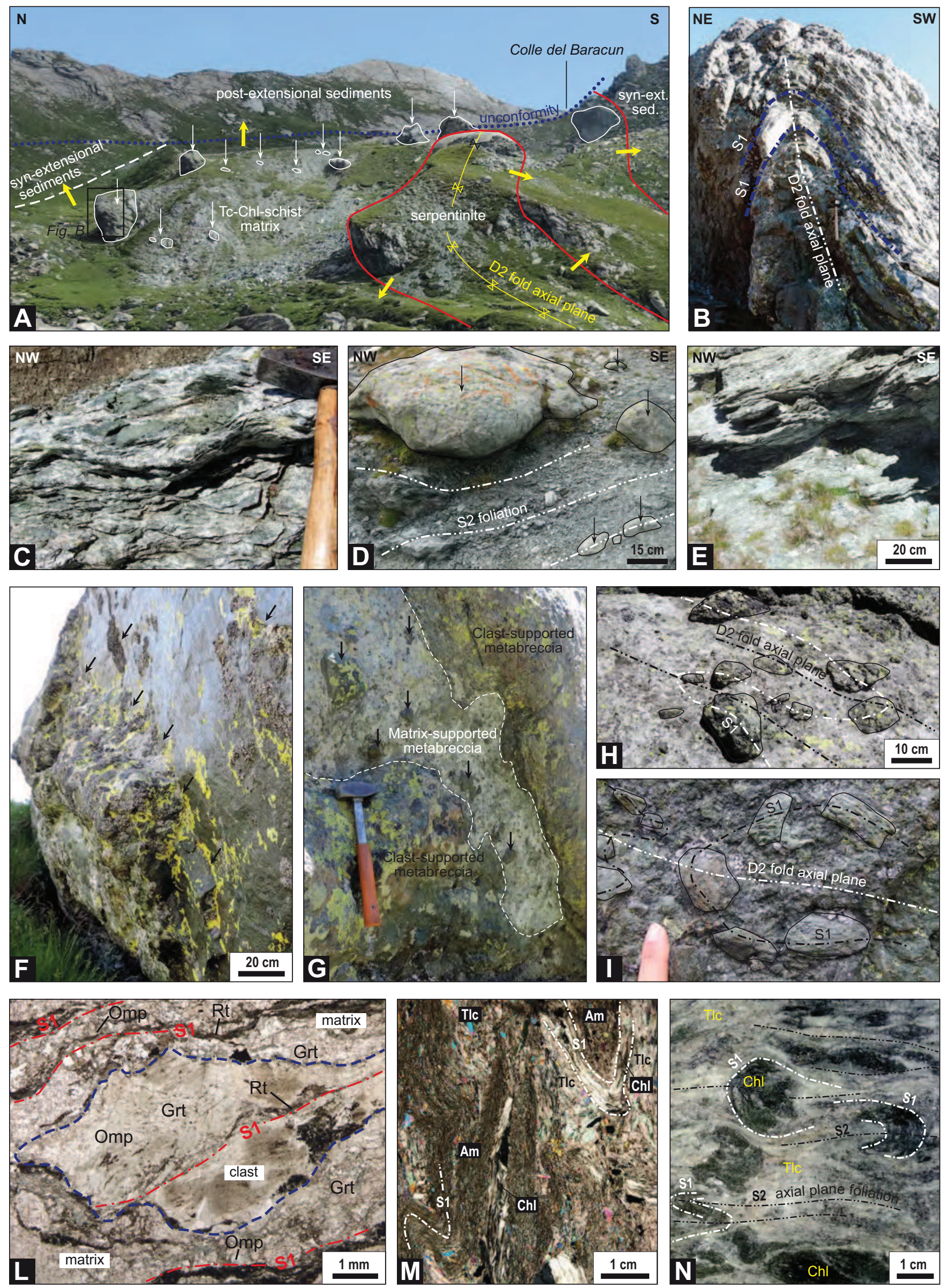
pyroxene, and is a result of the pre-Alpine alteration of gabbroic rocks. $\mathrm{Mg}-\mathrm{Al}$ metagabbro blocks are coarse-grained and more pervasively deformed in comparison to the Fe-Ti metagabbros. The mineral assemblages in these $\mathrm{Mg}$-Al metagabbros include: (a) Cr-omphacite accompanied by actinolite, tremolite and chlorite, and replacing magmatic pyroxene, (b) aggregates of clinozoisite and albite pseudomorphs after the original plagioclase, and (c) aggregates of rutile and titanite pseudomorph after ilmenomagnetite.

Differently from the metagabbros in the footwall (see below), the metagabbro blocks embedded in the BSZ do not show metasomatic rims (i.e. rodingitic reactions) against the serpentinite wallrock and the talc-chlorite schist matrix. But, they are enveloped by dm-thick layers of a clast-supported metabreccia (Figs. 3F-I), in which clasts are made of the same gabbroic rocks as in the blocks. This metabreccia envelope around the metagabbro blocks within the BSZ occurs throughout the entire LTU, and is overprinted by S1 foliation and D2 folds (Figs. 3H and 3I). We observe these mesoscopic structures and deformation fabrics at microscopic scales, as well; both micro-clasts and the matrix are foliated along the S1 foliation planes (Fig. 3L). These observations indicate that brecciation, fragmentation of blocks, and embedding of micro-clasts within a matrix must have occurred before the Alpine-stage deformation and the associated metamorphic overprint (see, Balestro et al., 2015, for details).

\section{BSZ footwall units}

The footwall block of the BSZ consists of serpentinized metaperidotites and metagabbros (Figs. 2 and 4). The serpentinized metaperidotites derive from lherzolite and minor harzburgite (Fig. $5 \mathrm{~A}$ ), and consist of oriented aggregates of antigorite and magnetite (S2 foliation) with minor diopside, Mg-chlorite, tremolite and Ticlinohumite. The original mineral assemblage is partly preserved in low-strain domains (e.g. in the cores of D2 folds exposed to the east of Colle Armoine), as evidenced by the relics of clinopyroxene and orthopyroxene porphyroclasts, and by olivine and spinel grains which are partially to entirely replaced by aggregates of antigorite and magnetite.

Metagabbro intrusions in the serpentinized metaperidotites form meters to hectometers thick and decameters to sub-kilometer long bodies. They range in texture from poorly foliated, coarse-grained pegmatitic gabbros (e.g. South of Colle Armoine; Fig. 5B) to pervasively foliated, anisotropic gabbros (Fig. 5C) (e.g. East of Colle del Baracun and West of Colle di Luca). Compositionally, they represent two sub-groups: $\mathrm{Mg}-\mathrm{Al}$ and $\mathrm{Fe}-\mathrm{Ti}$ metagabbros. The $\mathrm{Mg}$ Al metagabbros are characterized by the occurrence of $\mathrm{Cr}$-omphacite that replaced magmatic pyroxenes. The Fe-Ti metagabbros have a well-preserved garnet-omphacite-rutile eclogitic assemblage, which defines the $\mathrm{S} 1$ foliation. Contacts between the serpentinized metaperidotites and metagabbros are generally marked by rodingitic reaction rinds.

Serpentinite laced with irregular calcite vein networks (i.e., metaophicarbonate) is exposed along the contact between the footwall unit and the BSZ (Figs. 5D and 5E). Both in the Colle del Baracun and Colle Armoine sections, meta-ophicarbonate is few meters thick and shows a progressive transition from massive serpentinite to brecciated serpentinite with a white carbonate matrix, and up to a highly sheared meta-ophicarbonate rock (Fig. 5F). In the Colle di Luca section, the meta-ophicarbonate occurrence is no more than $30 \mathrm{~m}$ in thickness. Calcite veins in the meta-ophicarbonate rock are overprinted by $\mathrm{S} 1$ foliation and deformed by D2 folds, constraining the timing of hydrothermal activity that was responsible for the formation of ophicarbonates to a pre-Alpine stage (Festa et al., 2015a).

\section{BSZ hanging wall unit}

The hanging wall block of the BSZ includes metasedimentary and metabasaltic rocks spatially associated with minor metagabbro occurrences (Figs. 2 and 4). Metasedimentary units consist of calcschist layers interbedded with decimeters to sub-decameter thick horizons of mafic metasandstone and metabreccia (Figs. 2 and 4). The type locality of these rocks is at Colle del Baracun (Figs. 6A-C), where calcschist layers onlap the BSZ. The thickness of the entire calcschist unit increases from zero to 70 meters away from the shear zone (Figs. 2 and 4; see also Balestro et al., 2015; Festa et al., 2015a for details). At a regional scale and across the whole ophiolite, the thickness of the metasedimentary unit gradually decreases toward the south (i.e. between Colle Armoine and Colle di Luca sections). To the SW of Colle di Luca, a tens of meters - thick mafic metabreccia represents the syn-extensional unit.

The calcschist consists of subparallel layers of carbonate minerals (i.e. calcite, minor dolomite and ankerite), quartz and white mica, with subordinate chloritoid, $\mathrm{Mg}$-Fe chlorite, zoisite, and textural relics of lawsonite with graphite flakes. A matrix-supported mafic metabreccia unit is interbedded with calcschist layers, and shows a fining-upward texture with sub-angular to angular clasts of gabbroic rocks (Fig. 6B). The metabreccia is laterally gradational into tens of meters - thick metasandstone, containing similar composition but much smaller size clasts (Figs. 4 and 6C). The matrix of the mafic metabreccia and metasandstone is made of angular to irregularly shaped micro-clasts and grains, composed of omphacite and aggregates of chlorite, Cr-rich white mica, and epidote (pistacite). All these grains are in turn embedded in a groundmass of zoisite, light-green amphibole, epidote, albite, chlorite, sphene, quartz and white mica. These textural relationships at various scales indicate the detrital sedimentary nature of the protoliths of the mafic metabreccia and metasandstone.

The metabasaltic unit in the hanging wall of the BSZ is well exposed in the Colle Armoine section. It gradually decreases in thickness from this locale both toward Colle del Baracun and Colle di Luca (Figs. 2 and 4), and tapers out near Colle di Luca in the south. Mg-Al metagabbro outcrops with fine-grained metabasaltic dikes are in contact with metabasalts north of Colle di Luca. The primary breccia texture is still visible and well preserved in the metabasalt (Fig. 6D) despite the strong overprint of a well developed S2 foliation, defined by alternating layers of light green-yellow albite, epidote, clinozoisite with minor white mica, and dark-green layers of $\mathrm{Na}-\mathrm{Ca}$ amphibole, garnet and chlorite.

\section{Post-extensional metasedimentary sequence}

The footwall and hanging wall lithological units (syn-extensional metasedimentary and metabasaltic rocks) of the BSZ are unconformably overlain by a calcschist unit, which contains dm-thick marble beds (Figs. 2, 4, 7A and 7B), passing upward into layeredfoliated quartz-schist devoid of any ophiolite-derived detrital material. On the basis of a regional correlation of this calc schist-marble-quartz schist unit with other metasedimentary rocks in the Western Alps, 


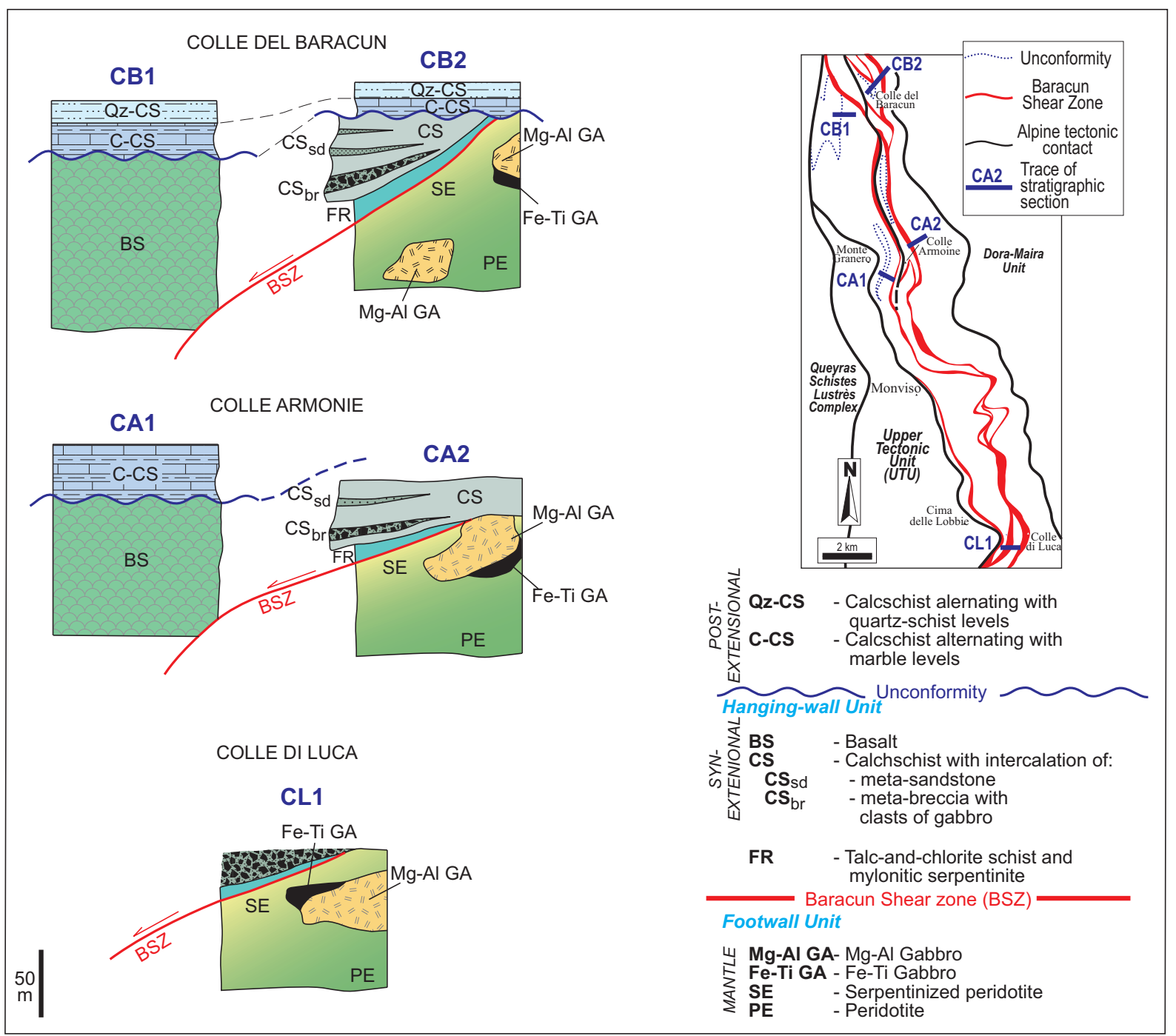

Figure 4-Simplified stratigraphic columnar sections, showing the tectono-stratigraphic relationships between the hanging wall-footwall units and the BSZ (traces are shown in the simplified geological map).

Lagabrielle (1994) established the age of the calcschist and the overlying syn-extensional rocks as the Lower Cretaceous. Festa et al. (2015a) defined these metasedimentary rocks in the hanging wall of the BSZ as post- extensional depositional units. The thickness of the post-extensional metasedimentary sequence within the Monviso ophiolite is irregular (Fig. 2) and ranges from few meters to tens of meters.

The calcschist unit consists of calcite, and minor dolomite with ankerite, quartz and white mica, whereas the marble and quartzrich schist are made of calcite and quartz, respectively. The contact between the post-extensional metasedimentary units and both the syn-extensional sedimentary sequence and the talc-chlorite schist of the BSZ is sharp and rugged (Figs. 7C-F), and corresponds to an original depositional surface as inferred from the lack of any mylonitic structure associated with it (Figs. 7E and 7F). This unconformity is folded together with the BSZ and the hanging wall and footwall units as seen at different structural levels in the field (Fig. 2).

\section{Geochemistry and mineralogy of the BSZ}

The composition of the talc-chlorite schist rocks within the BSZ was determined by major- and trace element chemistry analyses of selected rock samples, and by electron microprobe mineral analyses. The bulk rock geochemistry of the talc-chlorite schist was then compared with the compositional fields of the spatially associated serpentinite and metagabbro (Fig. 8). Compared to the serpentinite, the talc-chlorite schist rocks have higher values of $\mathrm{SiO}_{2}, \mathrm{Al}_{2} \mathrm{O}_{3}$ and $\mathrm{CaO}$, show lower values of $\mathrm{MgO}$, and are characterized by particularly strong enrichment in $\mathrm{TiO}_{2}$. On the other hand, compared to the metagabbro, the talc-chlorite schist is depleted in $\mathrm{Al}_{2} \mathrm{O}_{3}, \mathrm{CaO}$, total $\mathrm{Fe}$ and $\mathrm{Na}_{2} \mathrm{O}$, enriched in $\mathrm{MgO}$. The talc-rich rock also shows high absolute concentrations of $\mathrm{Cr}, \mathrm{Ni}$ and $\mathrm{V}$.

Electron microprobe mineral chemistry analyses reveal that chlorite in the talc-chlorite schist predominantly has a penninite (i.e., a Mg-rich solid solution between serpentine and amesite) composition $(\mathrm{XMg}=[0,83-0,89])$, with minor pycnochlorite $(\mathrm{XMg}=$ $0,79)$ and clinochlore $(\mathrm{XMg}=0,84-0,85)$ components. Some zoned chlorite grains are significantly enriched in $\mathrm{Cr}$ and in $\mathrm{Ni}$ in their centers. Chlorite also has relatively high chlorine content (up to $500 \mathrm{ppm})$.

Electron microprobe mineral chemistry analyses have shown that talc in the talc-chlorite schist is characterized by a negligible substitution of $\mathrm{Mg}$ by $\mathrm{Fe}(\mathrm{XFe}=[0,04-0,09])$, and that it contains high 

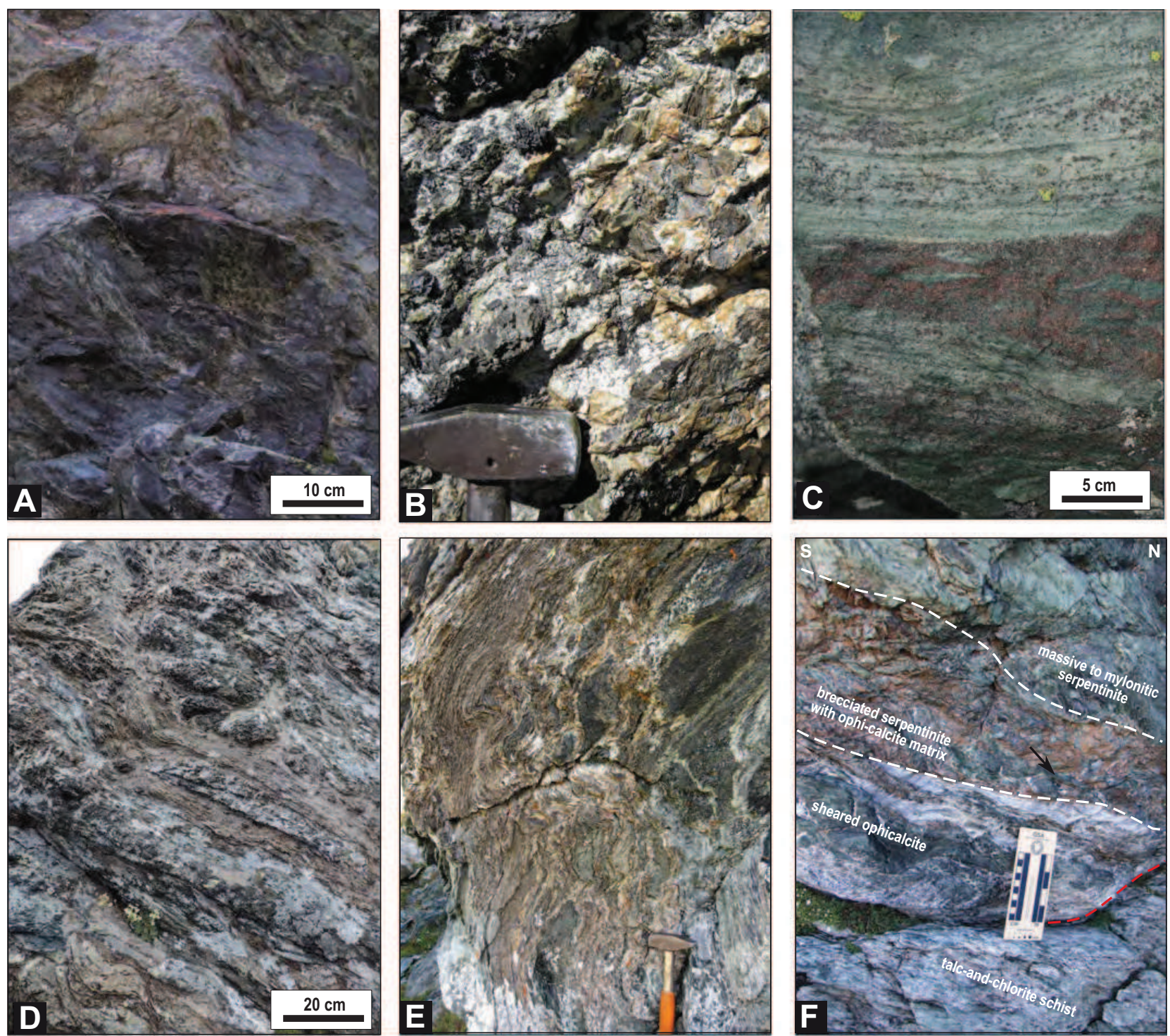

Figure 5. Field images of various lithologies and structures in the BSZ footwall unit: (A) Medium-grained, massive serpentinite with a lherzolitic protolith (East of Colle del Baracun); (B) Close-up of a pegmatitic, coarse-grained Mg-Al metagabbro (South of Colle Armoine). Hammer head as scale; (C) Close-up of a foliated, Mg-Al metagabbro with reddish Fe-Ti layers (W of Colle di Luca); (D) Sheared metaophicarbonate with light-brown carbonate layers, deformed by D2 folds (East of Colle Armoine); (E) Sheared meta-ophicarbonate marking the contact between the footwall sequence and the BSZ. Ophicarbonate rocks consists of serpentinite (dark green) meshed with white, cmto mm-thick hydrothermal calcite veins (South of Colle di Luca); (F) Close-up view of the overturned tectonic contact between the massive serpentinite in the footwall unit and the talc-chlorite schist within the BSZ at the Colle del Baracun. Note the progressive transition from the massive serpentinite to the pervasively sheared talc-chlorite schist.

$\mathrm{NiO}$ concentrations (highest $\mathrm{NiO}=0,32 \mathrm{wt} \%$ in talc lamellae included in apatite). Talc also has relatively high chlorine contents (up to $900 \mathrm{ppm})$.

\section{Discussion}

In this section, we discuss in a regional tectonic framework the significance of our structural, mineralogical and geochemical data, field observations, and interpretations from the Monviso ophiolite for: (1) its oceanic core complex origin, (2) the timing of this extensional tectonic episode and core complex development, and (3) the maturation of the Ligurian-Piedmont basin as a supradetachment depocenter within the Alpine Tethys.

\section{Oceanic core complex origin of the Monviso ophiolite and the BSZ}

The structural, textural and mineralogical evidence collectively indicate that the BSZ played a significant role in accommodating high-magnitude extension in young oceanic lithosphere and in the exhumation of lower crustal gabbros and upper mantle peridotites to the seafloor within the Ligurian-Piedmont ocean basin. This simpleshear extensional tectonics produced a Late Jurassic oceanic core complex, which is now represented by the multiply deformed Monviso ophiolite in the Western Alps (Figs. 9 and 10B). We infer that the mafic metabreccia within the BSZ and the talc-chlorite schist and mylonitic serpentinite matrix surrounding the metagabbro blocks 

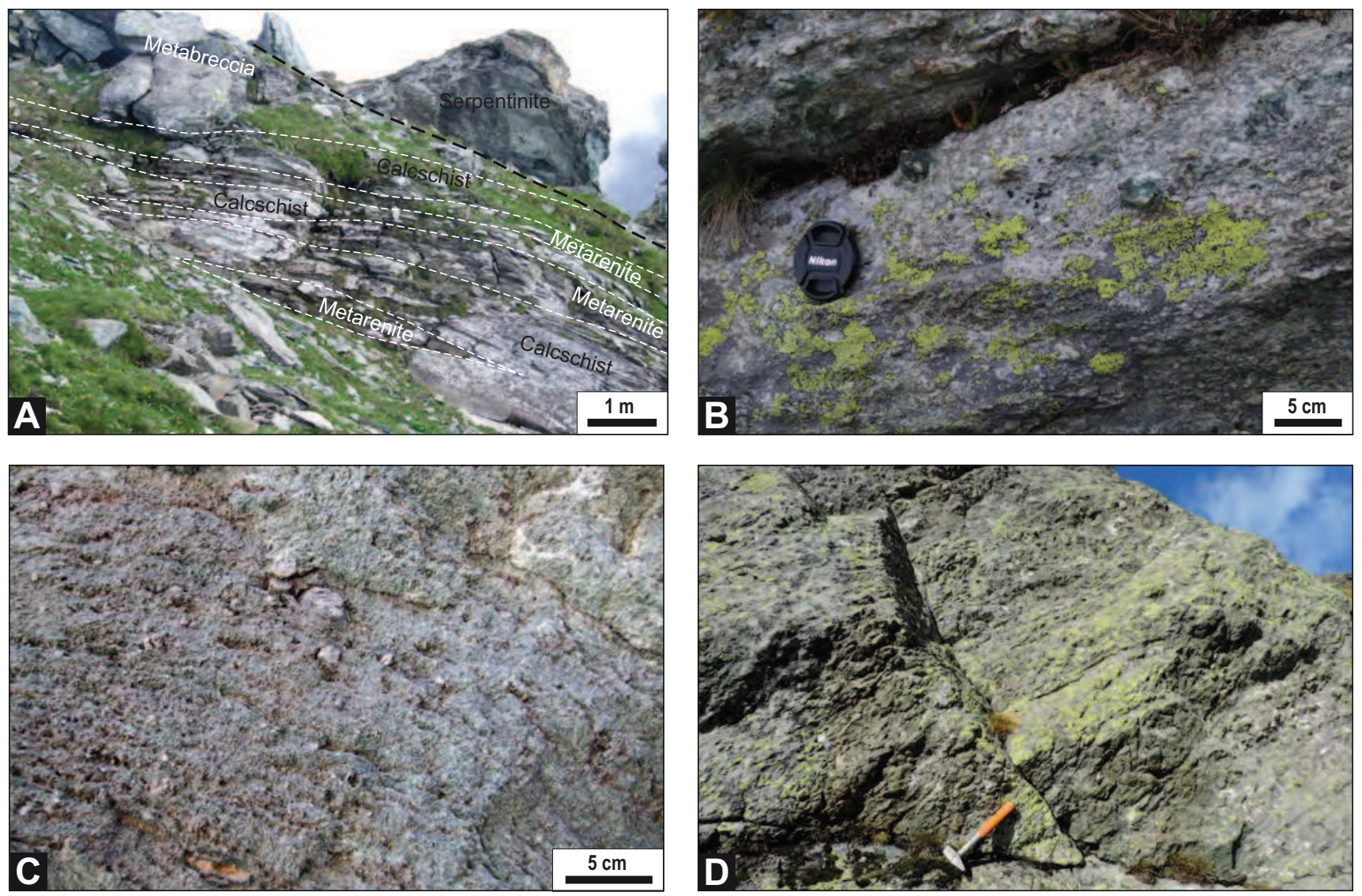

Figure 6 - Field images of various lithologies, contact relationships and structures in the BSZ hanging wall unit: (A) Panoramic view of the overturned mantle rocks and the cover sequence to the South of Colle del Baracun. Metasedimentary rocks consist of intercalations of mafic metabreccia and metasandstone horizons (dashed white lines), decimeters to several meters thick, that are interbedded with mediumto coarse-grained calcschist; (B) Close-up photo of the detrital texture of a matrix-supported mafic metabreccia layer characterized by rounded clasts, centimeters in size, embedded in the coarse-grained mafic matrix (NE of Colle del Baracun); (C) Close-up image of a fining-upward, matrix-supported, mafic metabreccia passing upward into a metasandstone rock (overturned sequence). Note the rounded shape of clasts (Colle del Baracun); (D) Metabasaltic rock with a relict brecciated texture (hammer for scale) (West of Colle Armoine).

represent a Late Jurassic intra-oceanic detachment fault. This lowangle detachment fault, which is now exposed along a 20-25-kmlong (Fig. 2), NNW-striking and W-to SW-dipping shear zone (Baracun Shear Zone), controlled the seafloor spreading tectonics and the exhumation of upper mantle peridotites on the seafloor as an oceanic core complex (Fig. 9). The kinematics of detachment faulting and the mode of the inferred uplift and exhumation of the upper mantle rocks in the footwall of the BSZ (Figs. 9 and 10B) are analogous to those documented from the in-situ core complexes along the slow(Atlantis Massif, Mid-Atlantic Ridge-MAR) and ultraslow-spreading (Atlantis Bank, Southwest Indian Ridge - SWIR) ridges (Cannat, 1993; Tucholke et al., 1998; Boschi et al., 2006; Karson et al., 2006; Dick et al., 2008; Miranda and Dilek, 2010).

Based on the results of the drilling and submersible studies of the Atlantis Bank (SWIR) and the Atlantis Massif (MAR), Miranda and Dilek (2010) defined gabbro-localized and peridotite-localized oceanic core complexes, respectively. In a gabbro-localized core complex, high-temperature, crystal-plastic deformation fabrics concentrate in the gabbros, and granulite-grade mylonitic rocks and shear zones appear to have formed the nucleation of detachmentrelated deformation in the presence of melt (Miranda and Dilek, 2010, and the references therein). In this type of oceanic core complex (such as SWIR), the footwall of the detachment fault includes widespread gabbroic intrusions in the serpentinized peridotites. In a peridotitelocalized core complex, gabbroic intrusions in the footwall peridotites are less abundant in comparison to those in gabbro-localized core complexes, and the crystal-plastic deformation fabrics occur both in peridotites and gabbros with increasingly more abundant low- $\mathrm{T}^{\circ} \mathrm{C}$ fabric elements affecting the serpentinized peridotites. Detachment faulting appears to have nucleated mainly in the peridotites in which strain partitioning and formation of talc-amphibolite-chlorite schists were taking place at temperatures more than $500^{\circ} \mathrm{C}$, following the emplacement of dispersed gabbros. The internal structure of the Monviso ophiolite and the BSZ detachment fault is more akin to that of a peridotite-localized oceanic core complex, such as the Atlantis Massif along the Mid-Atlantic Ridge ( $30^{\circ}$ Latitude). We posit that emplacement of the $\mathrm{Fe}-\mathrm{Ti}$ and $\mathrm{Mg}$-Al gabbros in the Monviso ophiolite and serpentinization of the peridotites along syn-kinematic fracture networks promoted rheological weakening of the ultramafic rocks and the development of the low-angle BSZ (MacLeod et al., 2002).

The upper mantle peridotites and oceanic lower crustal units exposed on the seafloor along the MAR commonly occur in the footwalls of detachment faults, which are characterized by tens to hundreds of meters thick, ductile to cataclastic shear zones (Figs. 10A, 10C, and 10D; Boschi et al., 2006, and reference therein). These structural fabrics represent the artifacts of hydrothermal fluid flow 

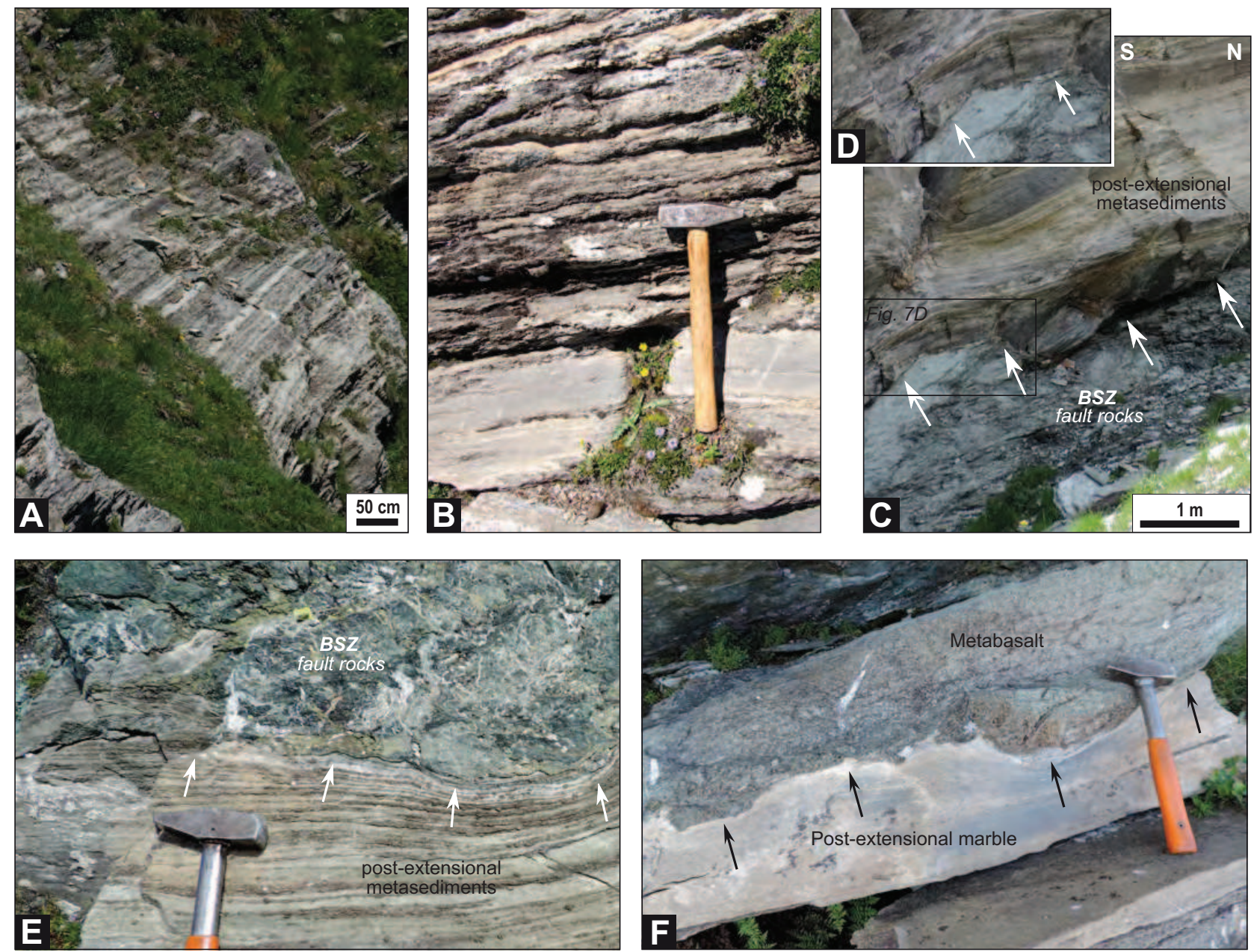

Figure 7 - Field images of various lithologies, contact relationships and structures in the post-extensional sedimentary sequence: (A) Panoramic view of the post-extensional sequence in the Colle del Baracun section, consisting of calcschist alternating with dm-thick marble layers; (B) Close-up of the outcrop in A, showing a dm-thick marble layer interbedded with calcschist (hammer for scale); (C, D, E) Different views of the post-extensional sequence, unconformably resting on the BSZ at Colle del Baracun. Note that the sequence is overturned in $E$; (F) Close-up photo of the overturned primary contact (black arrows) between a metabasalt and a white marble in the postextensional sequence (hammer for scale) (West of Colle Armoine).

and associated metasomatism, greenschist to sub-greenschist facies metamorphism (Escartin et al., 2008), and strain partitioning in heterogeneously distributed rocks below the detachment surface. The ubiquitous occurrence of talc-chlorite schist provides a weakening mechanism to allow a low-angle normal fault to initiate and to localize strain over long periods of time (Escartin et al., 2008).

Our observations in the Monviso ophiolite indicate a progressive transition from massive serpentinites to meta-ophicarbonate rocks, and higher up to a talc-chlorite schist shear zone, which represents the Late Jurassic detachment fault (Figs. 10B, 10E and 10F). Lowangle faulting in this case was accompanied by extensive hydrothermal metasomatism. Our mircrostructural observations and mineral chemistry data suggest that the talc-chlorite schist along the BSZ was a result of rock-fluid interactions between the gabbros and serpentinite, and seawater-derived hydrothermal fluids. High Ni and $\mathrm{Cr}$ concentrations in this schist rock are compositionally similar to those of chlorite and talc documented from detachment zone fault rocks in both the modern (Boschi et al., 2006) and ancient (Manatschal et al., 2011) oceanic core complexes. The relatively high chlorine contents in the talc-chlorite schist along the BSZ highlight the role of seawater-derived hydrothermal fluids percolating along-across the shear zone. Talc-rich rocks may form at early stages of faulting by interaction of hydrothermal fluids with upper mantle rocks exhumed to shallow depths on their way to the seafloor. This metasomatic process is critical in rheological weakening and strain localization, and facilitates the propagation of deformation farther down into the footwall rocks beneath the detachment surface, resulting in thickening of the detachment-induced shear zone (Fig. 10). Further propagation of brittle faults and fractures into the peridotites and gabbros in the footwall must have provided preferential pathways for seawater penetration and attendant hydration and serpentinization of the ultramafic rocks. This serpentinization process was likely to have contributed to the footwall uplift and exhumation, as documented from the MARK (Mid-Atlantic Ridge at Kane Fracture Zone) area in the modern oceanic lithosphere (Dilek et al., 1997).

\section{Timing of oceanic lithosphere formation in the Ligurian - Piedmont Ocean}

Diachronous crystallization ages of gabbros in the ophiolites of the Western Alps have been widely used for reconstructing the tectonic history of the Ligurian - Piedmont ocean basin (e.g., Lombardo et 

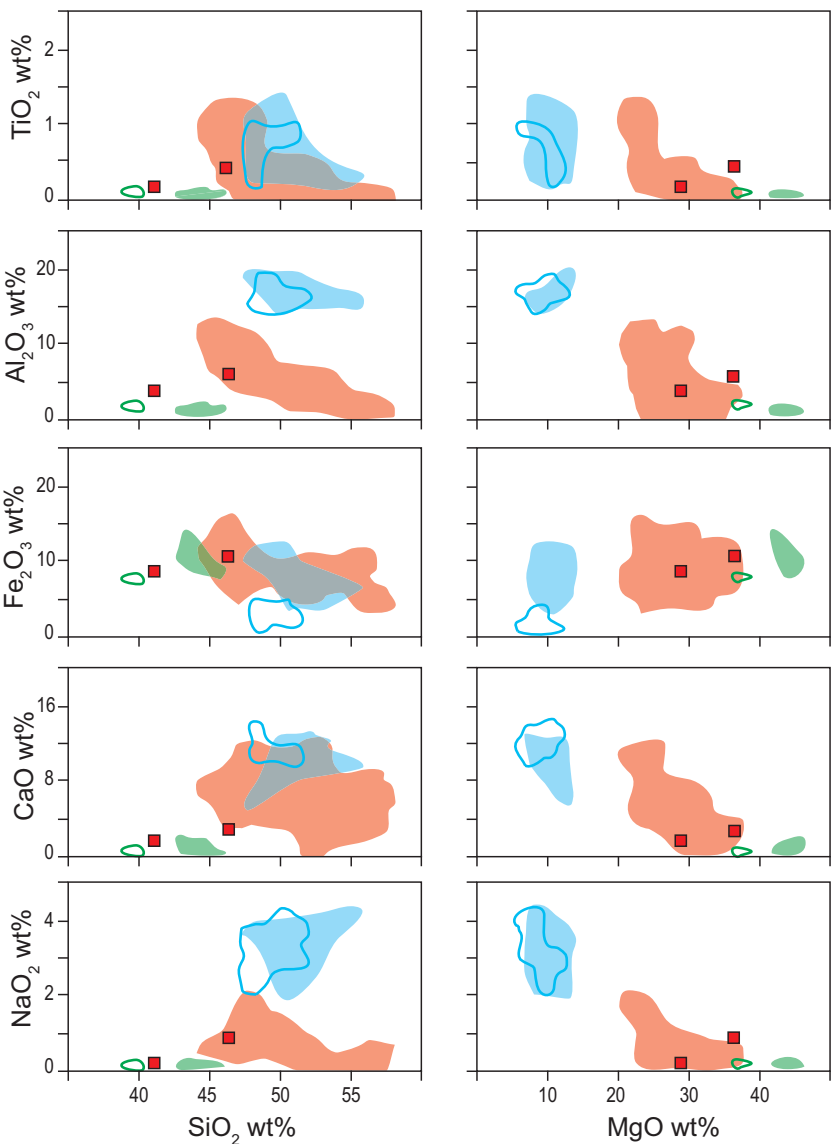

Figure 8 - Harker-type ( $\mathrm{SiO}_{2}$ and $\mathrm{MgO}$ ) and major-element variation diagrams of the talc-chlorite schist (red square) of the BSZ matrix. Green, red and light blue shaded areas show the compositional ranges of serpentinite, talc-chlorite schist and gabbro from the Atlantis Massif, respectively (modified from Boschi et al., 2006). Green and light-blue lines show the compositional ranges of serpentinized metaperidotites and metagabbros from the Monviso ophiolite, respectively (modified from Lombardo et al., 1978, Lafay et al., 2013).

al., 2002; Piccardo, 2009; Manatchal and Müntener, 2009). Assuming that the igneous ages of the ophiolitic gabbros reflect the magmatic accretion of oceanic lithosphere, the seafloor spreading and the extensional tectonic history of the Ligurian-Piedmont oceanic lithosphere can be quantified temporally. The zircon $\mathrm{U} / \mathrm{Pb}$ ages of the gabbro bodies within the Western Alps ophiolites (Fig. 11) range from $166 \pm 1 \mathrm{Ma}$ (in Gets) to $155 \pm 1.2 \mathrm{Ma}$ (in Antrona) (see, e.g., Lombardo et al., 2002 and Manatschal and Müntener, 2009, and reference therein), showing a close overlap with the biostratigraphic ages of the metaradiolarites spatially associated with the metabasalts. These ages collectively suggest that the oceanic lithosphere in the northern part of the Ligurian - Piedmont Ocean (Gets, 166 $\pm 1 \mathrm{Ma}$ ) and in the Zermatt-Saas (Allain gabbro, $163 \pm 5 \mathrm{Ma}$ ) meta-ophiolites formed nearly 10 m.y. before than the oceanic lithosphere, now preserved in the Antrona section ( $155 \pm 2 \mathrm{Ma}$ ) to the north. Farther to the south in the Western Alps, the igneous ages of the gabbros $(163 \pm 2$ My, Rubatto and Hermann, 2003; and Lanzo massif, 162 $\pm 2 \mathrm{Ma}$; Kaczmarek et al., 2008) are nearly coeval with those of the Voltri and Corsica ophiolite units (see, e.g., Piccardo, 2009; Fig. 11). Younger zircon $\mathrm{U} / \mathrm{Pb}$ ages obtained from plagiogranites (Fig. 11) in the Monviso ophiolite (152 $\pm 2 \mathrm{Ma}$, Lombardo et al., 2002) and in the
Chenalliet ophiolite massif (153 $\pm 3 \mathrm{Ma}$, Costa and Caby, 2001) likely represent a late-stage, off-axis magmatic episode in the igneous accretion history of the Ligurian - Piedmont oceanic lithosphere (see Lombardo et al., 2002). This latest pulse of magmatism in the Monviso ophiolite predated the unconformable deposition of the Lower Cretaceous post-extensional sediments overlying the intraoceanic Baracun detachment fault zone (BSZ).

The unconformity surface at the base of the Lower Cretaceous post-extensional sedimentary sequence seals the BSZ and onlaps both its hanging wall and footwall blocks. These stratigraphic relationships indicate that the structural architecture documented from the LTU of the Monviso ophiolite and the BSZ predates the deposition of these post-extensional rocks. Thus, the structural fabric elements and the primary mineral assemblages recorded in the rock units of the ophiolite and the BSZ reflect the rift-drift and seafloor spreading tectonic processes that took place during the opening of the Ligurian Piedmont ocean basin prior to the Early Cretaceous.

The exhumation of the upper mantle peridotites in the footwall and the deposition of the syn-extensional sediments in the hanging wall of the BSZ occurred during the Late Jurassic. We can constrain the specific timing of this extensional phase as between post $163 \pm 2$ $\mathrm{Ma}$ (Middle Callovian), which is the crystallization age of the gabbroic intrusions in the peridotites (Rubatto and Hermann, 2003) and the Early Cretaceous, which is the depositional age of the post-extensional sedimentary sequence above the unconformity. Meta-radiolarite rocks in the Queyras Schistes Lustrés Complex (Caby et al., 1987) represent the stratigraphic base of the post-extensional sequence and reveal a middle-late Oxfordian age for their deposition that is consistent with the age bracket we consider for the timing of simple-shear extension and detachment faulting.

The lack of any material or blocks within the BSZ derived from the hanging wall metasedimentary units or metabasaltic rocks also indicates that the main phase of detachment faulting must have occurred before the Alpine stage deformation. Although subductionto exhumation-related tectonic reworking of the Ligurian - Piedmont oceanic lithosphere and the associated metamorphic overprints partly obliterated the seafloor spreading history of the BSZ, its pre-Alpine stage record can be well constrained by several lines of meso- to micro-scale structural evidence: ( 1 ) ophicarbonate rocks resting on the massive serpentinite indicate that the upper mantle peridotites were already exhumed on the seafloor prior to the onset of subduction zone tectonics within the ocean basin. (2) pre-D1 metabreccia enveloping the metagabbro blocks within the BSZ represents a fault rock that formed during detachment faulting and the associated cataclastic deformation. (3) talc-chlorite schist matrix in the BSZ represents a metamorphic assemblage, which typically develops along intraoceanic detachment fault zones (see e.g., Boschi et al., 2006, and reference therein) due to syn-kinematic alteration at the contact between serpentinized peridotites and gabbros.

\section{Mature Ligurian-Piedmont ocean basin as a supradetachment depocenter}

The lateral and vertical facies variations in the meta-sedimentary sequences of the Monviso ophiolite and the structural relationships of these sequences with the mantle peridotites provide important clues for the nature of their depocenter within the Ligurian-Piedmont ocean basin. Development of this depocenter and its accommodation space was strongly controlled by asymmetric extension and tectonically 


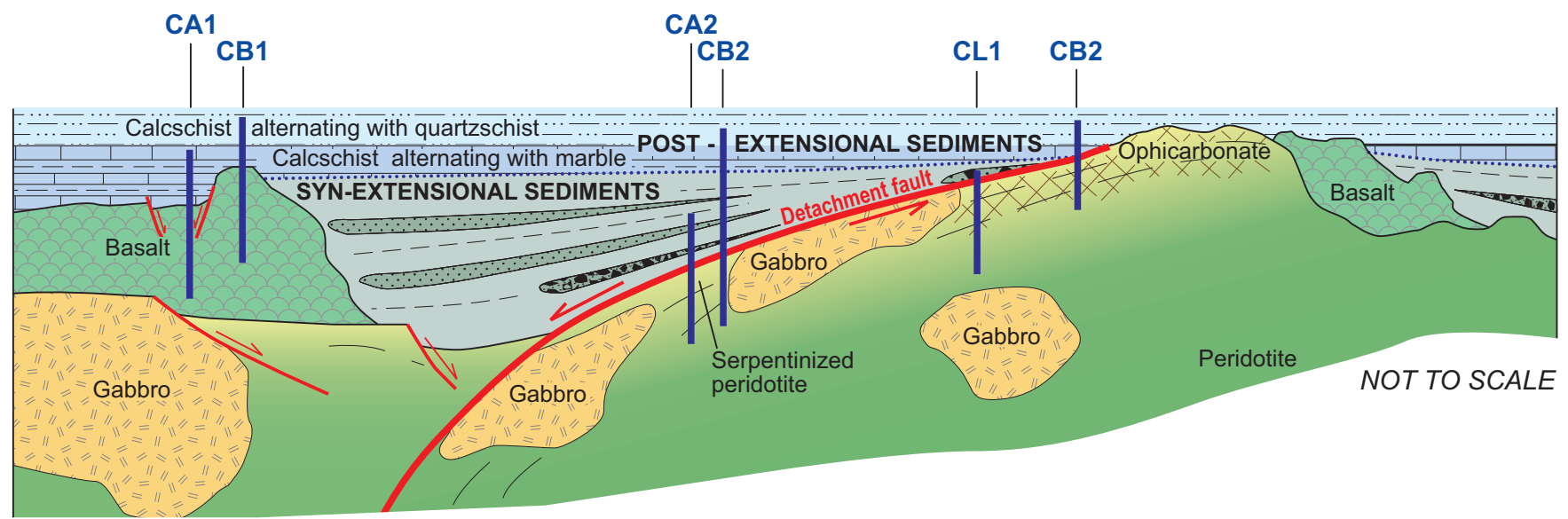

Figure 9 - Interpretive reconstruction of the Monviso ophiolite oceanic core complex, constrained by the analysis of the metasedimentary sequence and by the observed structural relationships between the hanging wall and footwall units of the extensional detachment fault (Baracun Shear Zone). Thick vertical blue lines (and related acronyms) indicate the approximate locations of the stratigraphic columnar sections shown in Figure 4.

MID-ATLANTIC RIDGE
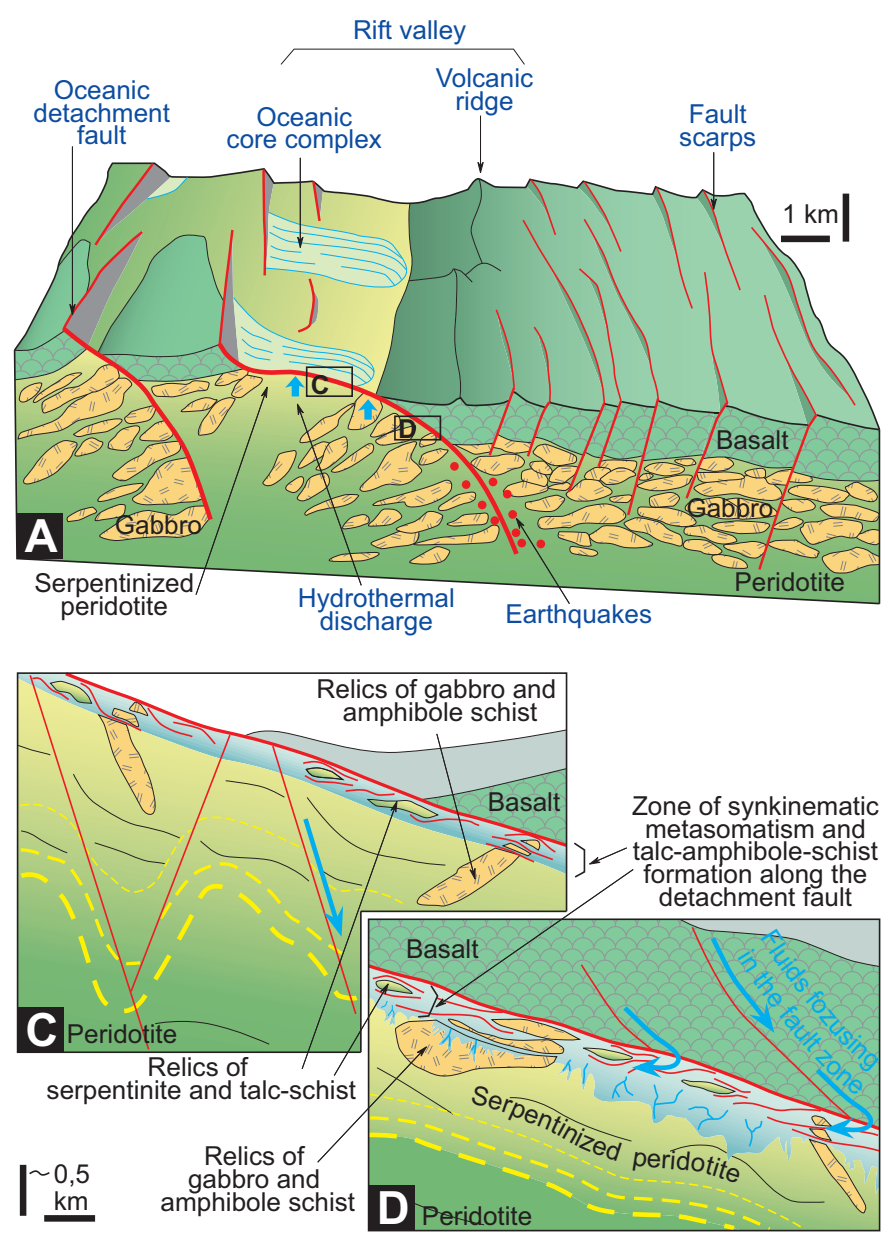

JURASSIC MONVISO OPHIOLITE
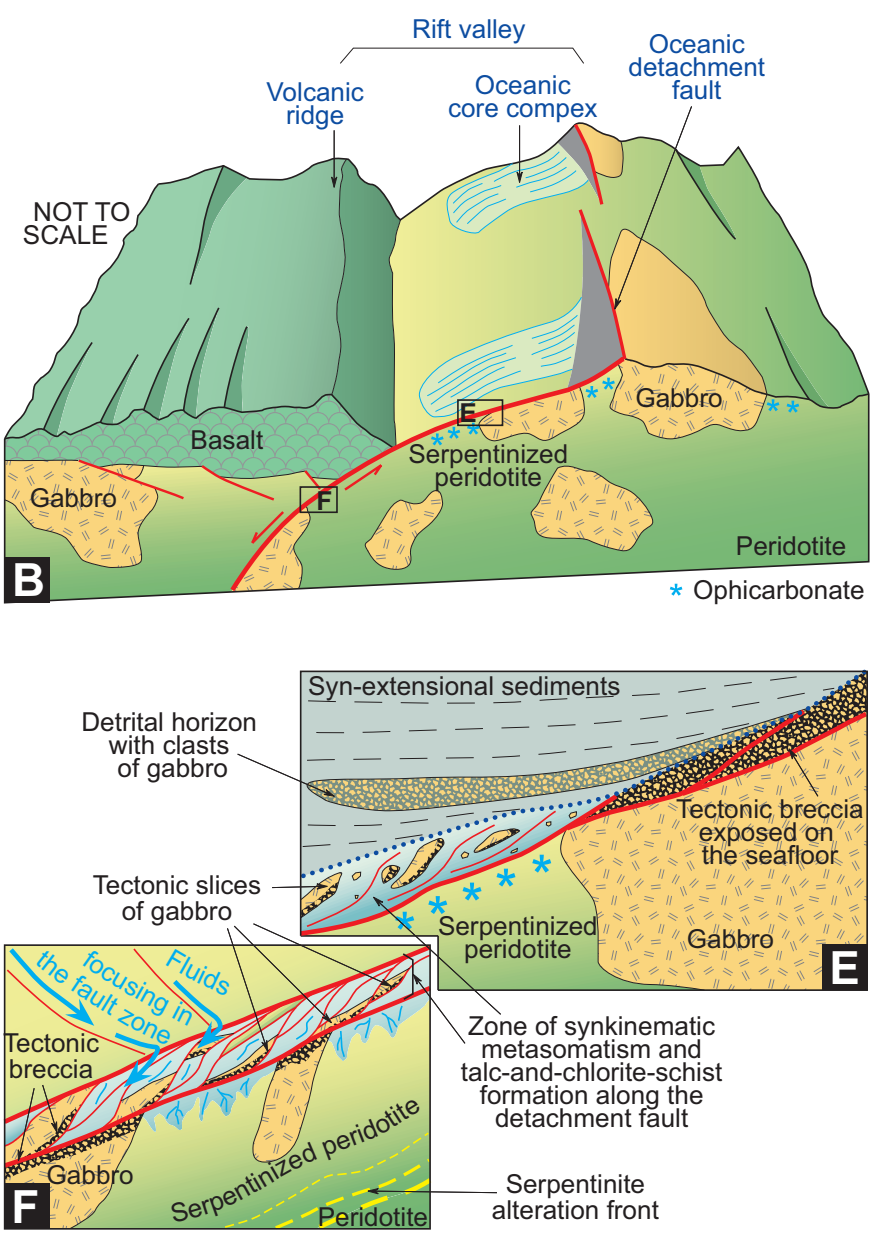

Figure 10 - Comparison between (A) an in-situ, intra-oceanic core complex along the Mid-Atlantic Ridge (modified from Escartin and Canales, 2011), and (B) the inferred Monviso oceanic core complex developed within the Jurassic Ligurian-Piedmont Ocean. (C-F) Closeup cross sections of a detachment fault system (location in Figs $10 \mathrm{~A}$ and 10B) and associated metasomatic and tectonic-processes in modern (C-D; modified from Boschi et al., 2006) and ancient oceanic (E-F) settings, respectively. 


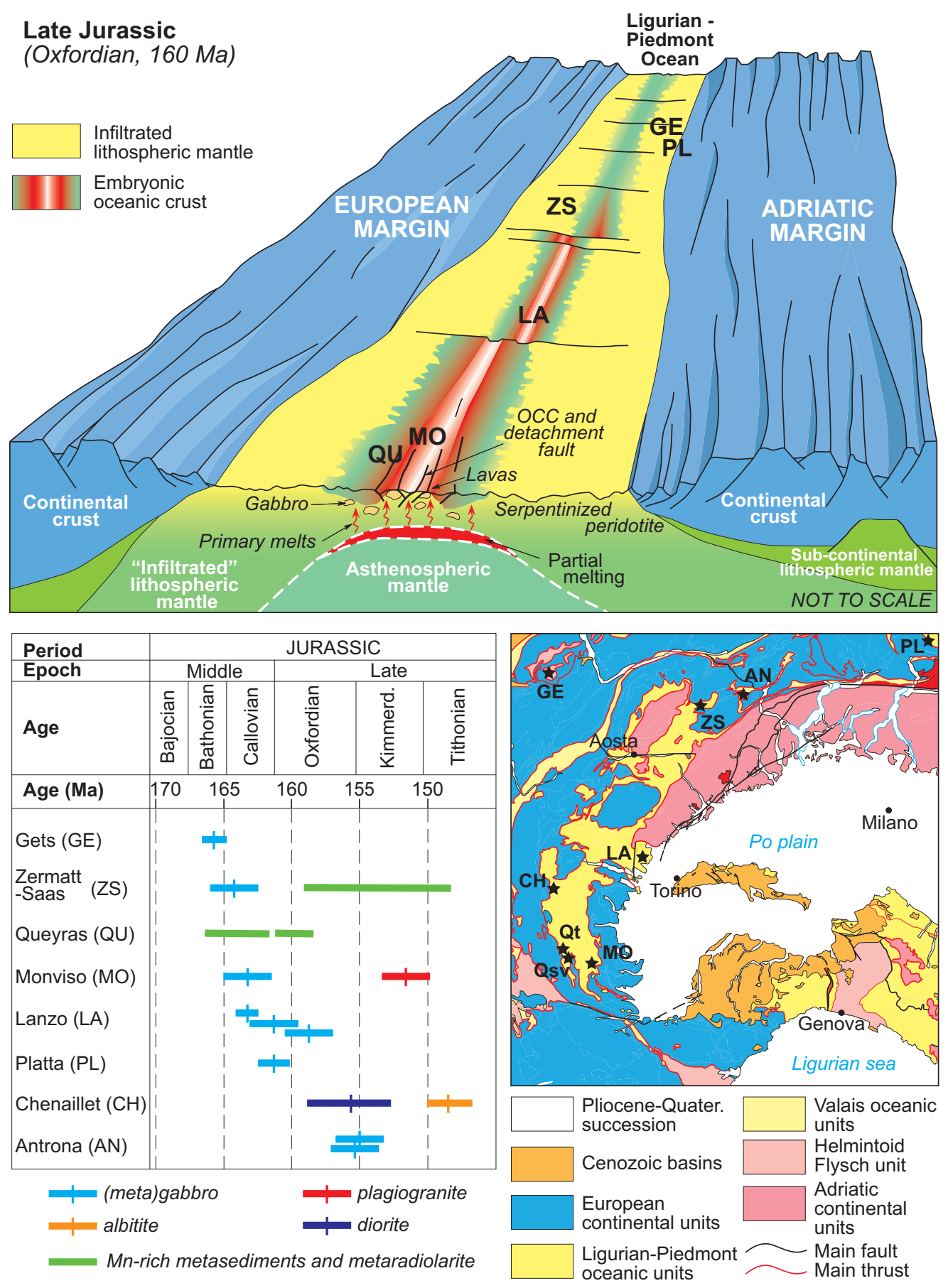

Figure 11 - Interpretive block diagram depicting the inferred paleogeography of the Monviso ophiolite ridge segment (MO) in the LigurianPiedmont Ocean in the Late Jurassic (Oxfordian, $160 \mathrm{Ma}$ ). Frontal cross-section modified from Dilek and Furnes (2011), Piccardo et al. (2009), Peron-Pinvidic and Manatschal (2009). Table in the lower left-side displays the known age ranges of mafic rocks, Mn-rich metasedimentary rocks, and meta-radiolarite from the Ligurian-Piedmont oceanic lithosphere (data sources: Borsi et al., 1996; Caby et al., 1987; Costa and Caby, 2001; De Wever and Beumagarter, 1995; Kaczmarek et al., 2008; Liati et al., 2005; Lombardo et al., 2002; Manatschal et al., 2006; Rubatto and Hermann, 2003; Rubatto et al., 1998; Stuki et al., 2003). Geological map of the Alps and the Northern Apennines shows the present-day location of the tectonostratigraphic units used in the entire figure.

controlled subsidence in the hanging wall of the low-angle Baracun detachment shear zone (Fig. 9). The Upper Jurassic syn-extensional sedimentary succession with abundant ophiolitic material onlaps the shear zone and its talc-chlorite schist rocks, and has a wedge shape geometry with its thickest section corresponding to the distal depocenter of the supradetachment basin.
The irregular thickness of the post-extensional sequence and its unconformable deposition on top of the footwall and hanging wall (metabasalts and metasediments) sequences and the BSZ rocks suggests an irregular seafloor bathymetry within the basin that was likely controlled by basement faulting and tectonic segmentation (Fig. 9). The thinner and incomplete sections of this sequence occur in the 
eastern part of the ophiolite where the Lower Cretaceous carbonaterich calcschists directly overlie the BSZ (Fig. 9). We interpret these bathymetric anomalies and the associated stratigraphic variations as tectonically controlled structural highs within a basin, which was deepening to the west (in the present coordinate system).

The initial input of continentally derived sediments within this basin did not occur until the deposition of the uppermost part of the post-extensional sequence that contains quartz-rich intercalations within the carbonate-rich calcschists. We postulate that this stage of deposition coincided with significant terrigenous input into the basin. In comparison with the analogous post-extensional sequences preserved in the unmetamorphosed Ligurian Units of the Northern Apennines (see, e.g., Decandia and Elter, 1972; Marroni et al., 2010; Festa et al., 2013, and references therein), we interpret these postextensional deposits to represent distal carbonatic and mixed siliciclastic-carbonatic turbidites (i.e., Calpionella Limestone and/or Palombini Shale) which reworked a continental margin source area.

\section{Conclusions}

This study is a first systematic documentation, from the Western Alps, of the seafloor spreading and oceanic core complex development history of the Late Jurassic Monviso ophiolite, which experienced subduction zone deformation and high-P metamorphism following its magmatic construction. Our structural, stratigraphic, mineralogical and geochemical analyses of the footwall and hanging wall tectonostratigraphic units in the ophiolite indicate that the upper mantle peridotites and their $\mathrm{Fe}-\mathrm{Ti}$ and $\mathrm{Mg}$-Al gabbroic intrusions were uplifted and exhumed on the seafloor as in an intraoceanic core complex. Emplacement of gabbroic intrusions into the ultramafic rocks, widespread extensional fracturing and attendant serpentinization in the peridotites, and hydrothermal metasomatism associated with faulting were instrumental in the localization of a low-angle detachment shear zone in the upper mantle. Peridotite rocks within this shear zone experienced crystal-plastic fabric development, recrystallization of talc-chlorite schist, and cataclastic brecciation, as shown from the modern peridotite-localized core complexes along the Mid-Atlantic Ridge seafloor spreading environment.

The timing of intraoceanic core complex development in the Piedmont-Ligurian ocean basin, as preserved in the Monviso ophiolite, is well constrained to have taken place between Middle Callovian $(163 \pm 2 \mathrm{Ma})$ and the middle-late Oxfordian. These ages reflect the timing of the emplacement of the gabbroic intrusions in the peridotites, and of the deposition of the post-extensional sedimentary sequence unconformably overlying the detachment shear zone and the synextensional deposits. Ophicarbonates and mafic breccias at the bottom of the syn-extensional deposits in the hanging wall record the early history of tectonically-induced sedimentation and accommodation space development above the shear zone. The wedge-shape geometry of the syn-extensional sequence, which thickens away from the Baracun shear zone, suggests a distal depocenter geometry as in a supradetachment basin configuration. Carbonate-rich calcschist with quartz-rich layers unconformably overlying the syn-extensional sequence and the ophiolite represent the post-extensional phase of deposition. The existence of continentally derived detrital material in this post-extensional sequence points to the proximal position of a continental margin to the Ligurian-Piedmont basin at this time.

The occurrence of a seafloor spreading originated oceanic core complex in the Monviso ophiolite is globally significant for two reasons: (1) Despite the strong overprint of subduction zone deformation and metamorphism, the simple-shear, intraoceanic extensional tectonic fabric is well preserved in the Late Jurassic oceanic lithosphere. This case study clearly demonstrates that not all shear zones, brittle-ductile and cataclastic structures, and highly dismembered ophiolites in high-pressure collisional belts generally represent the products of a subduction channel and subduction zone tectonics, as has been widely assumed in the literature pertaining to the Western Alps (i.e., Guillot et al., 2009; Angiboust et al., 2011). (2) Oceanic core complexes and their lithospheric-scale asymmetric shear zones (detachment faults) may be ideal tectonic settings for the localization of subduction initiation, as has been proposed from some other Tethyan ophiolites (i.e., Maffione et al., 2015). We think that inversion of extensional detachment faults into intraoceanic subduction zones under favorable geodynamic conditions provides a viable mechanism for basin collapse and closure without invoking other external driving forces in a given region.

\section{Acknowledgements}

This research has been supported by the following grants: (1) "ex 60\%-2013 and 2014" Università degli Studi di Torino and PROGEO Piemonte (Universita degli Studi di Torino and Compagnia San Paolo) to A. Festa and G. Balestro, (2) the Italian Ministry of University and Research Cofin-PRIN 2010/2011(“GEOPROB-GEOdynamic Processes of Oceanic Basins" to A. Festa and P. Tartarotti, and (3) "Subduction and exhumationof continental lithosphere: Implications on orogenic architecture, environment and climate" to G. Balestro. We gratefully acknowledge these funds. We thank M. Marroni, J. Wakabayashi and several other colleagues for providing us with insightful feedback and comments on various aspects of our study in the Monviso ophiolite, as presented in this paper.

\section{References}

Angiboust, S., Agard, P., Raimbourgh, H., Yamato, P., and Huet, B., 2011, Subduction interface processes recorded by eclogite-facies shear zones (Monviso, W. Alps): Lithos, v. 127, pp. 222-238. doi:10.1016/ j.lithos.2011.09.004

Angiboust, S., Langdon, R., Agard, P., Waters, D., and Chopin, C., 2012, Eclogitization of the Monviso ophiolite (W. Alps) and implications on subduction dynamics: Journal of Metamorphic Geology, v. 30, pp. $37-$ 61. doi:10.1111/j.1525-1314.2011.00951.x

Balestro, G., Fioraso, G., and Lombardo, B., 2011, Geological map of the upper Pellice Valley (Italian Western Alps): Journal of Maps, 2011, pp. 634-654. doi: 10.4113/jom.2011.1213.

Balestro, G., Fioraso, G., and Lombardo, B., 2013, Geological map of the Monviso massif (Western Alps): Journal of Maps, v. 9(4), pp. 623-634. doi: 10.1080/17445647.2013.842507.

Balestro, G., Lombardo, B., Vaggelli, G., Borghi, A., Festa, A., and Gattiglio, M., 2014, Tectonostratigraphy of the northern Monviso Meta-ophiolite Complex (Western Alps): Italian Journal of Geosciences, v. 133 (3), pp. 409-426. Doi: 10.3301/IJG.2014.13

Balestro, G., Festa, A., and Tartarotti, P., 2015, Tectonic significance of different block-in-matrix structures in exhumed convergent plate margins: examples from oceanic and continental HP rocks in Inner Western Alps (northwest Italy): International Geology Review, v. 57, no. 5-8, pp. 581605. http://dx.doi.org/10.1080/00206814.2014.943307.

Bearth, P., 1967, Die Ophiolithe der Zone von Zermatt-Saas Fee: Beiträge zur Geologischen Karte der Schweiz, Neue Folge, 132, 130 pp.

Bigi, G., Castellarin, A., Coli, M., Dal Piaz, G.V., Sartori, R., Scandone, P. and Vai, G.B., 1990, Structural Model of Italy, sheets 1-2: CNR, Progetto Fin. Geodinamica, SELCA Firenze 
Bill, M., O’Dogherty, L., Guex, J., Baumgartner, P.O., Masson, H., 2001, Radiolarite ages in Alpine-Mediterranean ophiolites: constraints on the oceanic spreading and the Tethys-Atlantic connection: Geological Society of America Bulletin, v. 113, pp. 129-143.

Borsi, L., Schärer, U., Gaggero, L., and Crispini, L., 1996, Age, origin and geodynamic significance of plagiogranites in lherzolites and gabbros of the Piedmont-Ligurian ocean basin: Earth and Planetary Science Letters, v. 140 , pp. 227-241.

Boschi, C., Früh-Green, G.L., and Delacour, A., 2006, Mass transfer and fluid flow during detachment faulting and development of an oceanic core complex, Atlantis Massif (MAR 30 $\mathrm{N}$ ): Geochemistry, Gephysics, Geosystem, v. 7, doi: 10.1029/2005GC001074.

Bousquet, R., Schimid, S.M., Zeilinger, G., Oberhansli, R., Roseberg, C., Molli, G., Robert, C., Wiederkehr, M., Rossi, Ph., 2012, Tectonic framework of the Alps: CCGM/CGMW. 1 sheet.

Butler, J.P., Beaumont, C., and Jamieson, R.A., 2013, The Alps 1: A working geodynamic model for burial and exhumation of (ultra)high-pressure rocks in Alpine-type orogens: Earth and Planetary Science Letters, v. 377-378, pp. 114-131. doi:10.1016/j.eps1.2013.06.039

Caby R., Dupuy C. and Dostal J., 1987, The very beginning of the Ligurian Tethys in the Western Alps: Petrological and geochemical evidence from the oldest ultramafite-derived sediments in Queyras, Western Alps (France): Eclogae Geologicae Helvetiae, v. 80, pp. 223-240.

Cannat, M., 1993, Emplacement of mantle rocks in the seafloor at Mid-Ocean ridge: Journal of Geophysical Research, v. 98, B3, pp. 4163-4172.

Costa, S., and Caby, R., 2001, Evolution of the Ligurian Tethys in the Western Alps: $\mathrm{Sm} / \mathrm{Nd}$ and $\mathrm{U} / \mathrm{Pb}$ geochronology and rare-earth element geochemistry of the Montgenèvre ophiolite (France): Chemical Geology, v. 175 , pp. $449-466$.

Coward, M.P., and Dietrich, D., 1989, Alpine tectonics-an overview, in Coward M.P., Dietrich D., Park R.G., eds., Alpine tectonics: Geological Society of London Special Publications, v. 45, pp. 1-29. doi:10.1144/ GSL.SP.1989.045.01.01

Dal Piaz, G.V., Bistacchi, A., and Massironi, M., 2003, Geological outline of the Alps: Episodes, v. 26, pp. 175-180.

Dal Piaz, G.V., Hunziker, J.C., and Martinotti, G., 1972, La zona Sesia-Lanzo e l'evoluzione tettonico metamorfica delle Alpi nordoccidentali interne: Memorie della Società Geologica Italiana, v. 11, pp. 433-460.

Decandia, F.A., and Elter, P., 1972, La "zona" ofiolitifera del Bracco nel settore compreso fra Levanto e la Val Graveglia (Appennino ligure): Memorie della Società Geologica Italiana, v. 11, pp. 503-530.

De Wever P. and Baumgartner P.O., 1995, Radiolarians from the base of the supra-ophiolitic Schistes Lustrés formation in the Alps (Saint-Véran, France and Traversiera Massif, Italy), in Baumgartner P.O. et al., eds., Middle Jurassic to Lower Cretaceous radiolaria of Tethys: occurrences, systematics, biochronology: Memoire Géologique, Lausanne, v. 23, pp. 725-730

Dick, H.J.B., Tivey, M.A., and Tucholke, B.E., 2008, Plutonic foundation of a slow-spreading ridge segment: Oceanic core complex at Kane Megamullion, 23_300N, 45_200W: Geochemistry, Geophysics, Geosystems, v. 9, Q05014, doi:10.1029/2007GC001645.

Dilek, Y., 2003, Ophiolite pulses, mantle plumes and orogeny. Geological Society of London, Special Publications, v. 218, pp. 9-19.

Dilek,Y., 2006, Collision tectonics of the Eastern Mediterranean region:Causesandconsequences: Geological Society of America Special Paper, v. 409,pp.1-13.

Dilek, Y. and Delaloye, M., 1992, Structure of the Kizildag ophiolite, a slowspread Cretaceous ridge segment north of the Arabian promontory: Geology, v. 20, pp. 19-22

Dilek, Y. and Eddy, C.A., 1992, The Troodos (Cyprus) and Kizildag (S. Turkey) ophiolites as structural models for slow-spreading ridge segments: Journal of Geology, v. 100, pp. 305-322.

Dilek, Y., Coulton, A. and Hurst, S., 1997, Serpentinization and hydrothermal veining in peridotites at Site 920 in the MARK area (Leg153). In: Cannat, J. Karson, J. Miller and D. Elthon, eds., Proceedings of the Ocean Drilling Program, Scientific Results, v. 153: College Station, Texas (Ocean Drilling Program), pp.35-59.

Dilek, Y., Moores, E.M., and Furnes, H., 1998, Structure of modern oceanic crust and ophiolites and implications for faulting and magmatism at oceanic spreading centers: In, Buck, R., Karson, J., Delaney, P., and Lagabrielle, Y., eds., AGU Monograph on Faulting and Magmatism at Mid-Ocean Ridges, v. 106, pp. 219-266.
Dilek, Y. and Thy, P., 1998, Structure, petrology, and seafloor spreading tectonics of the Kizildag ophiolite (Turkey). In, Mills, R., and Harrison, K., eds., Modern Ocean Floor Processes and the Geological Record: Geological Society of London Special Publication, v. 148, pp. 43-69.

Dilek, Y. and Newcomb. S., 2003, Ophiolite Concept and the Evolution of Geological Thought: Geological Society of America Special Paper, v. 373, 504 pp. ISBN 0-8137-23736.

Dilek, Y. and Robinson, P.T., 2003, Ophiolites in Earth history. Geological Society, London, Special Publications, v. 218, pp. 1-8.

Dilek, Y. and Furnes, H., 2011, Ophiolite genesis and global tectonics: geochemical and tectonic fingerprinting of ancient oceanic lithosphere: The Geological Society of America Bulletin, v. 123, pp. 387-411, DOI: 10.1130/B30446.1.

Dilek, Y., and Furnes, H., 2014, Ophiolites and their origins: Elements, v. 10, p. 93-100, doi:10.2113/gselements.10.2.93.

Elter G., 1971, Schistes lustrés et ophiolites de la zone piemontaise entre Orco et Doire Baltée (Alpes Graies). Hypotèses sur l'origine des ophiolites: Gèologie Alpine, v. 47, pp. 147-169.

Escartin, J., and Canales, J.P., 2011, Detachments in oceanic lithosphere: Deformation, magmatism, fluid flow and ecosystems: Eos, Transactions, American Geophysical Union, v. 92, pp.31, http://dx.doi.org/10.1029/ 2011EO040003.

Escartýn, J., Smith, D.K., Cann, J., Schouten, H., Langmuir, C.H., and Escrig, S., 2008, Central role of detachment faults in accretion of slowspread oceanic lithosphere: Nature, v. 455, pp. 790-794, doi:10.1038/nature 07333.

Fantoni, R., Bersezio, R., and Forcella, F., 2004, Alpine structre and deformation chronology at the Southern Alps-Po Plain border in Lombardy: Bollettino della Società Geologica Italiana, v. 123, pp. 463476.

Fantoni, R., Decarlis, A., and Fantoni, E., 2003, L'estensione mesozoica al margine occidentale delle Alpi meridionali (Piemonte settentrionale, Italia): Atti Ticinensi di Scienze della Terra, v. 44, pp. 97-110.

Festa, A., 2011, Tectonic, sedimentary, and diapiric formation of the Messinian mélange: Tertiary Piedmont Basin (northwestern Italy), inWakabayashi, J., and Dilek, Y., eds., Mélanges: Processes of Formation and Societal Significance: Geological Society of America Special Paper 480, pp. 215232, doi:10.1130/2011.2480(10).

Festa A., Balestro, G., Dilek Y, and Tartarotti, P., 2015a, A Jurassic oceanic core complex in the high-pressure Monviso ophiolite (western Alps, NW Italy): Lithosphere, v. 7, pp. 646-652, Doi: 10.1130/L458.1.

Festa A., Dilek., Y., Codegone G., Cavagna, S., and Pini, G.A., 2013, Structural Anatomy of the Ligurian Accretionary Wedge (Monferrato, NW-Italy), and Evolution of Superposed Mélanges: Geological Society of America Bulletin, v. 125 (9/10), pp. 1580-1598. Doi: 10.1130/B30847.1

Festa, A., Dilek, Y., Pini, G.A., Codegone, G., and Ogata, K., 2012, Mechanisms and processes of stratal disruption and mixing in the development of mélanges and broken formations: redefining and classifying mélanges: Tectonophysics, v. 568-569, pp. 7-24. DOI: 10.1016/j.tecto.2012.05.021

Festa A., Fioraso G, Bissacca E., and Petrizzo M.R., 2015b, Geology of the Villalvernia-Varzi Line between Scrivia and Curone valleys (NW Italy), in Zucali M., and Spalla, I., eds., Structural Mapping in the Mediterranean: bridging laboratory to lithosphere: Journal of Maps, v. 11 (1), pp. 39-55. Doi: 10.1080/17445647.2014.959569.

Festa, A., Ogata, K., Pini, G.A., Dilek, Y., and Codegone, G., 2015c, Late Oligocene - early Miocene olistostromes (sedimentary mélanges) as tectono-stratigraphic constraints to the geodynamic evolution of the exhumed Ligurian accretionary complex (Northern Apennines, NW Italy): International Geology Review, v. 57, no. 5-8, pp. 540-562. Doi: 10.1080/ 00206814.2014 .931260 .

Funicello, R., Parotto, M., Praturlon, A., and Bigi, G., 1981, Carta tettonica d'Italia - schema preliminare: CNR-Consiglio Nazionale delle Ricerche. Ed. Grafica editoriale cartografica, Roma. 1 sheet. 1:1.500.000 scale.

Frey, M., Desmons, J. and Neubauer, F., eds, 1999, The new metamorphic map of the Alps: Schweizrische Mineralogische und Petrogrographische Mitteilungen, v. 79, pp. 1-230.

Ghibaudo, G., Massari, F., and Chiambretti, I., 2014, Oligo-Miocene tectonosedimentary evolution of the Langhe Sub-basin: from continental basinal setting (Tertiary Piedmont Basin - Northwestern Italy): Journal of Mediterranean Earth Sciences, v. 6, pp. 53-144. 
Ghielmi, M., Minervini, M., Nini, C., Rogledi, S., and Rossi, M., 2013, Late Miocene - Middle Pleistocene sequences in the Po Plain - Northern Adriatic Sea (Italy): The stratigraphic record of modification phases affecting a complex foreland basin: Marine and Petroleum Geology, v. 42 , pp. $50-81$.

Groppo, C., and Castelli, D., 2010, Prograde P-T evolution of a lawsonite eclogite from the Monviso Meta-ophiolite (Western Alps): Dehydration and redox reactions during subduction of oceanic FeTi-oxide gabbro: Journal of Petrology, v. 51, pp. 2489-2514. doi:10.1093/petrology/ egq065.

Guillot, S., Hattori, K., Agard, P., Schwartz, S., and Vidal, O., 2009, Exhumation processes in oceanic and continental subduction contexts: A review, in Lallemand, S., and Funiciello, F., eds., Subduction zone geodynamics: Berlin Heidelberg, Springer-Verlag, pp. 275.

Kaczmarek, M.-A., Müntener, O., Rubatto, D., 2008, Trace element chemistry and $\mathrm{U}-\mathrm{Pb}$ dating of zircons oceanic gabbros and their relationship with whole rock composition (Lanzo, Italian Alps): Contributions to Mineralogy and Petrology, v. 155, pp. 295-312.

Karson J.A., Fruh-Green, G.L., Kelley, D.S., Williams,E.A., Yoerger, D.R. and Jakuba, M., 2006, Detachment shear zone of the Atlantis Massif core complex, Mid-Atlantic Ridge, $30^{\circ} \mathrm{N}$ : Geochemistry, Geophysics, Geosystems, v.7(6), Q06016, doi: 10.1029/2005GC001109.

Lagabrielle, Y., 1994, Ophiolites of the southwestern Alps and the structure of the Tethyan oceanic lithosphere: Ofioliti, v. 19, 413-434.

Lagabrielle, Y., 2009, Mantle exhumation and lithosphere spreading: An historical perspective from investigations in the oceans and in the AlpsApennines ophiolites: Italian Journal of Geosciences, v. 128 (2), pp. 279293.

Lardeaux, J., Schwartz, S., Tricart, P., Paul, A., Guillot, S., Béthoux, N., and Masson, F., 2006, A crustal-scale crosssection of the south-western Alps combining geophysical and geological imagery: Terra Nova, v. 18, no. 6 , pp. 412-422. doi:10.1111/j.1365-3121.2006.00706.X

Lafay, R., Deschamps, F., Scghwartz, S., Guillot, S., Godard, M., Debret, B., and Nicollet, C., 2013, High-pressure serpentinites, a trap-and-release system controlled by metamorphic conditions: Example from the Piedmont zone of the western Alps: Chemical Geology, v. 343, pp. 3854.

Laubscher, H.P., 1991, The arc of Western Alps today: Eclogae Geologicae Helvetiae, v. 84, pp. 631-659.

Lemoine, M., 1971, Données nouvelles sur la série du Gondran près Briançon (Alpes Cottiennes). Réflexions sur les problèmes stratigraphique et paléogéographique de la zone piémontaise: Gèologie Alpine, v. 47, pp. 181-201.

Lemoine, M., and Tricart, P., 1986, Les schistes lustrés piémontais des Alpes occidentales: approche stratigraphique, structurale et sédimentologie: Eclogae Geologicae Helvetiae, v. 79, pp. 271-294.

Liati, A., Froitzheim, N., and Fanning, C.M., 2005, Jurassic ophiolites within the Valais domain of the Western and Central Alps: geochronological evidence for re-rifting of oceanic crust: Contributions to Mineralogy and Petrology, v. 149 (4), pp. 446-461.

Lombardo, B., Nervo, R., Compagnoni, R., Messiga, B., Kienast, J., Mevel, C., Fiora, L., Piccardo, G., and Lanza, R., 1978, Osservazioni preliminari sulle ofioliti metamorfiche del Monviso (Alpi Occidentali): Rendiconti Società Italiana Di Mineralogia E Petrologia, v. 34, pp. 253-305.

Lombardo, B., Rubatto, D., and Castelli, D., 2002, Ion microprobe U-Pb dating of zircon from a Monviso metaplagiogranite: Implications for the evolution of the Piedmont-Liguria Tethys in the Western Alps: Ofioliti, v. 27, pp. 109-117.

MacLeod, C.J., Escartin, J, Banerji, D., Banks, G.J., Gleeson, M., Irving, D.H.B., Lilly, R.M., McCaig, A.M., Niu, Y., Allerton, S., and Smith, D.K., 2002, Direct geological evidence for oceanic detachment faulting: The Mid-Atlantic Ridge, 15_450N: Geology, v 30, pp. 879-882.

Maffione, M., Thieulot, C., van Hinsbergen, D.J.J, Morris, A., Plumper, O., and Spakman, W., 2015, Dynamics of intra-oceanic subduction initiation. 1: Oceanic detachment fault inversion and the formation of forearc ophiolites: Geochemistry, Geophysics, Geosystems, v. 16 (6), pp. 17531770. doi:10.1002/2015GC005746.

Manatschal, M., and Müntener, O., 2009, A type sequence across an ancient magma-poor ocean-continent transition: the example of the western Alpine Tethys ophiolites: Tectonophysics, v. 473, pp. 4-19.

Manatschal, G., Engstrom, A., Desmurs, L., Schaltegger, U., Cosca, M., Müntener, O., and Bernoulli, D., 2006. What is the tectono-metamorphic evolution of continental break-up: the example of the Tasna OceanContinent Transition: Journal of Structural Geology, v. 28 (10), pp. 18491869.

Manatschal, G., Sauter, D., Karpoff, A.M., Masini, E., Mohn, G., and Lagabrielle, Y., 2011, TheChenaillet Ophiolite in the French/Italian Alps: an ancient analogue for an Oceanic Core Complex?: Lithos, v. 124, pp. 169-184. http://dx.doi.org/10.1016/j.lithos.2010.10.017.

Manzotti, P., Ballèvre, M., Zucali, M., Robyr, M. and Engi, M., 2014, The tectonometamorphic evolution of the Sesia-Dent Blanche nappes (internal Western Alps): review and synthesis: Swiss Journal of Geosciences, v.107, pp. 309-336.

Marroni, M., Meneghini, F., and Pandolfi, L., 2010, Anatomy of the LigurePiemontese subduction system: Evidence from Late Cretaceous-middle Eocene convergent margin deposits in the Northern Apennines, Italy: International Geology Review, v. 52, pp. 1160-1192.

Michard, A., Goffe, B., Chopin, C., and Henry, C., 1996, Did the Western Alps develop through an Oman-type stage? The geotectonic setting of high-pressure metamorphism in two contrasting Tethyan transects: Eclogae Geologicae Helvetiae, v. 89, pp. 43-80.

Miranda, E.A. and Dilek, Y., 2010, Oceanic core complex development in modern and ancient oceanic lithosphere: Gabbro-localized versus peridotite-localized detachment models: Journal of Geology, v. 118, pp. 95-109, DOI: 10.1086/648460.

Péron-Pinvidic, G., and Manatschal, G., 2009, The final rifting evolution at deep magma-poor passive margins from Iberia-Newfoundland: a new point of view: International Journal of Earth Sciences, v. 98, pp. 15811597.

Perrone, G., Cadoppi, P., and Tallone, S., 2015, Geometry and impact of transpressional faulting in polyphasic metamorphic orogenic belts: the Viù Deformation Zone (inner Western Alps): International Geology Reviewv. 50 (11), pp. 1022-1039. doi: 10.1080/00206814.2015.1033655.

Piccardo, G., 2009, Evolution of the lithospheric mantle in an extensional setting: Insights from ophiolitic peridotites: Lithosphere, v.1, pp. 81-87.

Platt, J.P., Behrmann, J.H., Cunningham, P.C., Dewey, J.F., Helman, M., Parish, M., Shepley, M.G., Wallis, S., and Western, P.J., 1989, Kinematics of the Alpine arc and the motion history of Adria: Nature, v. 337, pp. 158-161.doi:10.1038/337158a0.

Ricou, L.E., and Siddans, W.B., 1986, Collision tectonics in the western Alps: Geological Society, London, Special Publications, v. 19, pp. 229-244. doi:10.1144/GSL.SP.1986.019.01.13.

Rubatto, D., and Hermann, J., 2003, Zircon formation during fluid circulation in eclogites (Monviso, Western Alps): implications for $\mathrm{Zr}$ and $\mathrm{Hf}$ budget in subduction zones: Geochimica et Cosmochimica Acta, v. 67 (12), pp. 2173-2187.

Rubatto, D., Gebauer, D., Fanning, M., 1998. Jurassic formation and Eocene subduction of the Zermatt-Saas-Fee ophiolites: implications for the geodynamic evolution of the Central and Western Alps: Contributions to Mineralogy and Petrology, v. 132, pp. 269-287.

Saccani, E., Dilek, Y., Marroni, M., and Pandolfi, L., 2015, Continental margin ophiolites of Neotethys: Remnants of ancient Ocean-Continent Transition Zone (OCTZ) lithosphere and their geochemistry, mantle sources and melt evolution patterns. Episodes, v. 38, No. 4, pp. 230-249, doi:10. 18814/epiiugs/2015/v38i4/82418.

Schmid, S.M., and Kissling, E., 2000, The arc of the western Alps in the light of geophysical data on deep crustal structure: Tectonics, v. 19, pp. 62 85. doi:10.1029/1999TC900057.

Stampfli. G.M. and Marthaler. M., 1990, Divergent and convergent margins in the North-Western Alps confrontation to actualistic models: Geodinamica Acta, v. 4., pp. 159-184.

Stucki, A., Rubatto, D., and Trommsdorff, V., 2003, Mesozoic ophiolite relics in the Southern Steep Belt of the Central Alps. Schweizerische Mineralogische und Petrographische Mitteilungen, v. 83, pp. 285-299.

Tricart, P., and Lemoine, M., 1991, The Queyras ophiolite west of Monte Viso (Western Alps): indicator of a peculiar ocean floor in the Mesozoic Tethys: Journal of Geodynamics, v. 13, pp.163-181.

Tricart, P., and Schwartz, S., 2006, A north-south section across the Queyras Schistes lustrés (Piedmont zone, western Alps): Syn-collision refolding of a subduction wedge: Eclogae Geologicae Helvetiae, v. 99, pp. 429442 .

Tucholke, B., Lin, J. and Kleinrock, M.C., 1998, Megamullions and mullion structure defining oceanic metamorphic core complexes on the MidAtlantic Ridge: Journal of Geophysical Research, v. 103, pp. 9857-9866. 